\title{
Metal Effect on the Supramolecular Structure, Photophysics, and Acid-Base Character of Trinuclear Pyrazolato Coinage Metal Complexes ${ }^{\dagger}$
}

\author{
Mohammad A. Omary, ${ }^{*}$ Manal A. Rawashdeh-Omary, M. W. Alexander Gonser, Oussama Elbjeirami, \\ Tom Grimes, and Thomas R. Cundari*
}

Department of Chemistry, University of North Texas, Denton, Texas 76203

Himashinie V. K. Diyabalanage, Chammi S. Palehepitiya Gamage, and H. V. Rasika Dias*

Department of Chemistry and Biochemistry, The University of Texas at Arlington, Arlington, Texas 76019

Received May 31, 2005

\begin{abstract}
Varying the coinage metal in cyclic trinuclear pyrazolate complexes is found to significantly affect the solid-state packing, photophysics, and acid-base properties. The three isoleptic compounds used in this study are $\{[3,5-$ $\left.\left.\left(\mathrm{CF}_{3}\right)_{2} \mathrm{Pz}\right] \mathrm{M}\right\}_{3}$ with $\mathrm{M}=\mathrm{Cu}, \mathrm{Ag}$, and $\mathrm{Au}$ (i.e., $\mathrm{Cu}_{3}, \mathrm{Ag}_{3}$, and $\mathrm{Au}_{3}$, respectively). They form isomorphous crystals and exist as trimers featuring nine-membered $\mathrm{M}_{3} \mathrm{~N}_{6}$ rings with linear two-coordinate metal sites. On the basis of the $\mathrm{M}-\mathrm{N}$ distances, the covalent radii of two-coordinate $\mathrm{Cu}^{\prime}, \mathrm{Ag}^{\prime}$, and $\mathrm{Au}^{\prime}$ were estimated as 1.11, 1.34, and $1.25 \AA$, respectively. The cyclic $\left\{\left[3,5-\left(\mathrm{CF}_{3}\right)_{2} \mathrm{Pz}\right] \mathrm{M}\right\}_{3}$ complexes pack as infinite chains of trimers with a greater number of pairwise intertrimer $\mathrm{M} \cdots \mathrm{M}$ interactions upon proceeding to heavier coinage metals. However, the intertrimer distances are conspicuously short in $\mathrm{Ag}_{3}(3.204 \AA)$ versus $\mathrm{Au}_{3}(3.885 \AA)$ or $\mathrm{Cu}_{3}(3.813 \AA)$ despite the significantly larger covalent radius of $\mathrm{Ag}$ ! Remarkable luminescence properties are found for the three $\mathbf{M}_{3}$ complexes, as manifested by the appearance of multiple unstructured phosphorescence bands whose colors and lifetimes change qualitatively upon varying the coinage metal and temperature. The multiple emissions are assigned to different phosphorescent excimeric states that exhibit enhanced $\mathrm{M} \cdots \mathrm{M}$ bonding relative to the ground state. The startling luminescence thermochromic changes in crystals of each compound are related to relaxation between the different phosphorescent excimers. The trend in the lowest energy phosphorescence band follows the relative triplet energy of the three $\mathrm{M}^{\mathrm{l}}$ atomic ions. DFT calculations indicate that $\left\{\left[3,5-(\mathrm{R})_{2} \mathrm{Pz}\right] \mathrm{M}\right\}_{3}$ trimers with $\mathrm{R}=\mathrm{H}$ or Me are bases with the relative basicity order $\mathrm{Ag} \ll \mathrm{Cu}<\mathrm{Au}$ while fluorination $\left(\mathrm{R}=\mathrm{CF}_{3}\right)$ renders even the $\mathrm{Au}$ trimer acidic. These predictions were substantiated experimentally by the isolation of the first acid-base adduct, $\left\{\left[\mathrm{Au}_{3}\right]_{2}: \text { toluene }\right\}_{\infty}$, in which a trinuclear $\mathrm{Au}^{\prime}$ complex acts as an acid.
\end{abstract}

\section{Introduction}

Cyclic trinuclear complexes of $\mathrm{d}^{10}$ transition metal ions represent an important class of coordination compounds whose significance spans multiple fundamental areas, including acid-base chemistry, metalloaromaticity, metallophilic bonding, supramolecular assemblies, $\mathrm{M}-\mathrm{M}$-bonded excimers and exciplexes, and host/guest chemistry. ${ }^{1-8}$ Significant optoelectronic applications are anticipated for members of this class in view of the fascinating luminescence properties

* To whom correspondence should be addressed. E-mail: omary@unt.edu (M.A.O.); tomc@unt.edu (T.R.C.); dias@uta.edu (H.V.R.D.).

$\dagger$ Dedicated to Professor John Fackler on his 70th birthday. reported and their sensitivity to multiple stimuli. For example, Balch reported that $\left\{\mu^{\mathrm{C}, \mathrm{N}}-[\mathrm{MeOC}=\mathrm{NMe}] \mathrm{Au}\right\}_{3}$ exhibits "solvoluminescence", ${ }^{3 a}$ in which a spontaneous yellow emission is observed upon contact with solvent following

(1) (a) Burini, A.; Mohamed, A. A.; Fackler, J. P., Jr. Comments Inorg Chem. 2003, 24, 253. (b) Omary, M. A.; Mohamed, A. A.; RawashdehOmary, M. A.; Fackler, J. P., Jr. Coord. Chem. Rev. 2005, 249, 1372.

(2) (a) Tsipis, C. A.; Karagiannis, E. E.; Kladou, P. F.; Tsipis, A. C. J. Am. Chem. Soc. 2004, 126, 12916. (b) Tsipis, A. C.; Tsipis, C. A. J. Am. Chem. Soc. 2003, 125, 1136.

(3) (a) Vickery, J. C.; Olmstead, M. M.; Fung, E. Y.; Balch, A. L. Angew. Chem., Int. Ed. Engl. 1997, 36, 1179. (b) Olmstead, M. M.; Jiang, F.; Attar, S.; Balch, A. L. J. Am. Chem. Soc. 2001, 123, 3260. (c) Hayashi, A.; Olmstead, M. M.; Attar, S.; Balch, A. L. J. Am. Chem. Soc. 2002 , 124,5791 .

10.1021/ic0508730 CCC: $\$ 30.25$ @ 2005 American Chemical Society Published on Web 09/10/2005 
irradiation with long-wavelength UV light. Related cyclic $\mathrm{Au}^{\mathrm{I}}$ trimers form deeply colored charge-transfer stacks with nitro-substituted 9-fluorenones ${ }^{3 \mathrm{~b}}$ while some undergo gold deposition reactions on standing in air leading to hourglass figures within the crystals. ${ }^{3 \mathrm{c}}$ Fackler, Burini, and co-workers reported supramolecular stacks with visible luminescence that can be altered on interaction of nucleophilic imidazolate and/ or carbeniate $\mathrm{Au}^{\mathrm{I}}$ complexes with several types of electrophiles that include $\mathrm{Tl}^{+}$and $\mathrm{Ag}^{+}$cations, ${ }^{4 \mathrm{a}}$ a fluorinated cyclic trinuclear $\mathrm{Hg}^{\mathrm{II}}$ neutral complex, ${ }^{4 \mathrm{~b}}$ and organic Lewis acids or electron acceptors. ${ }^{1,4 \mathrm{c}}$ Aida et al. reported the design of trinuclear $\mathrm{Au}^{\mathrm{I}}$ complexes that exhibit metallophilic interactions that lead to self-assembled dendritic "superhelical fibers" ${ }^{\circ a}$ and RGB phosphorescent organogels. ${ }^{6 \mathrm{~b}}$ Gabbaï and co-workers reported the sensitization of room-temperature phosphorescence of polycyclic aromatic organic molecules upon interaction with $\left[o-\mathrm{C}_{6} \mathrm{~F}_{4} \mathrm{Hg}\right]_{3},{ }^{7 \mathrm{a}-\mathrm{c}}$ a similar phenomenon has been reported by Omary and Fackler for the interaction of perfluoronaphthalene with an electron-rich trinuclear $\mathrm{Au}^{\mathrm{I}}$ complex. ${ }^{9}$ We have recently reported that a variety of trinuclear $\mathrm{Cu}^{\mathrm{I}}$ pyrazolates exhibit fascinating optical phenomena that include luminescence thermochromism, luminescence solvatochromism, luminescence rigidochromism, and concentration luminochromism. ${ }^{8}$ Despite the extensive attention given to cyclic trinuclear $\mathrm{d}^{10}$ complexes, a fundamental issue that remains outstanding regards the role played by the transition metal in determining the supramolecular structure, photophysics, and acid-base character of these trimeric complexes. This paper reports the first systematic effort to unravel the role of the coinage metal in a series of analogous cyclic trinuclear complexes. In particular, we describe the structures, luminescence, and acid-base properties of the trimeric $\mathrm{Cu}^{\mathrm{I}}, \mathrm{Ag}^{\mathrm{I}}$, and $\mathrm{Au}^{\mathrm{I}}$ complexes shown in Chart 1 featuring a highly fluorinated pyrazolate $\left[3,5-\left(\mathrm{CF}_{3}\right)_{2}-\right.$ $\mathrm{Pz}]^{-}$ligand.

\section{Results and Discussion}

Synthesis and Structural Properties. The synthesis of $\left\{\left[3,5-\left(\mathrm{CF}_{3}\right)_{2} \mathrm{Pz}\right] \mathrm{Cu}\right\}_{3}$ and $\left\{\left[3,5-\left(\mathrm{CF}_{3}\right)_{2} \mathrm{Pz}\right] \mathrm{Ag}\right\}_{3}$ involves the use of the corresponding metal(I) oxide and $\left[3,5-\left(\mathrm{CF}_{3}\right)_{2^{-}}\right.$

(4) (a) Burini, A.; Bravi, R.; Fackler, J. P., Jr.; Galassi, R.; Grant, T. A.; Omary, M. A.; Pietroni, B. R.; Staples, R. J. Inorg. Chem. 2000, 39, 3158. (b) Burini, A.; Fackler J. P., Jr.; Galassi, R.; Grant, T. A.; Omary, M. A.; Rawashdeh-Omary, M. A.; Peitroni, B. R.; Staples, R. J. J. Am. Chem. Soc. 2000, 122, 11264. (c) Rawashdeh-Omary, M. A.; Omary, M. A.; Fackler, J. P., Jr.; Galassi, R.; Pietroni, B. R.; Burini, A. J. Am. Chem. Soc. 2001, 123, 9689.

(5) Yang, G.; Raptis, R. G. Inorg. Chem. 2003, 42, 261.

(6) (a) Enomoto, M.; Kishimura, A.; Aida, T. J. Am. Chem. Soc. 2001, 123, 5608. (b) Kishimura, A.; Yamashita, T.; Aida, T. J. Am. Chem. Soc. 2005, 127, 179.

(7) (a) Omary, M. A.; Kassab, R. M.; Haneline, M. R.; Elbjeirami, O.; Gabbaï, F. P. Inorg. Chem. 2003, 42, 2176. (b) Haneline, M. R.; Tsunoda, M.; Gabbaï, F. P. J. Am. Chem. Soc. 2002, 124, 3737. (c) Burress, C.; Elbjeirami, O.; Omary, M. A.; Gabbaï, F. P. J. Am. Chem. Soc. 2005, 127, 12166. (d) Tsunoda, M.; Gabbaï, F. P. J. Am. Chem. Soc. 2000, 122, 8335 .

(8) (a) Dias, H. V. R.; Diyabalanage, H. V. K.; Rawashdeh-Omary, M. A.; Franzman, M. A.; Omary, M. A. J. Am. Chem. Soc. 2003, 125, 12072. (b) Dias, H. V. R.; Diyabalanage, H. V. K.; Eldabaja, M. G.; Elbjeirami, O.; Rawashdeh-Omary, M. A.; Omary, M. A. J. Am. Chem. Soc. 2005, 127, 7489.

(9) Mohamed, A. A.; Rawashdeh-Omary, M. A.; Omary, M. A.; Fackler, J. P., Jr. Dalton Trans. 2005, 2597.
Chart 1. Structure of $\left\{\left[3,5-\left(\mathrm{CF}_{3}\right)_{2} \mathrm{Pz}\right] \mathrm{M}\right\}_{3}$ Complexes $\left(\mathbf{M}_{3}\right)$

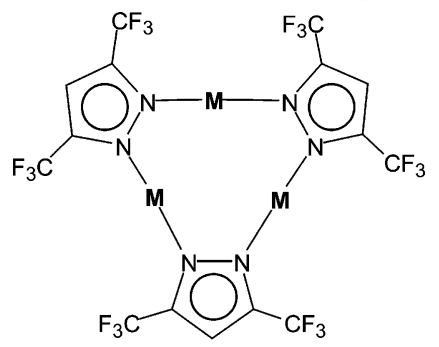

$\mathrm{Pz}] \mathrm{H} .{ }^{10}\left\{\left[3,5-\left(\mathrm{CF}_{3}\right)_{2} \mathrm{Pz}\right] \mathrm{Au}\right\}_{3}$ was prepared using $\left[3,5-\left(\mathrm{CF}_{3}\right)_{2}-\right.$ $\mathrm{Pz}] \mathrm{H}, \mathrm{NaH}$, and $\mathrm{Au}(\mathrm{THT}) \mathrm{Cl}$ in THF, representing a slight modification of the literature synthesis. ${ }^{11}$ These $\left\{\left[3,5-\left(\mathrm{CF}_{3}\right)_{2-}\right.\right.$ $\mathrm{Pz}] \mathrm{M}\}_{3}$ complexes $\left(\mathbf{M}_{\mathbf{3}}\right)$ are colorless crystalline solids. X-ray-quality crystals of $\mathbf{A g}_{3}$ and $\mathbf{A u}_{3}$ were obtained from $\mathrm{CH}_{2} \mathrm{Cl}_{2}$ at $-25{ }^{\circ} \mathrm{C}$ whereas the copper analogue $\mathrm{Cu}_{3}$ was crystallized from hexane. Table 1 shows the unit cell dimensions and important structural parameters for the three $\mathbf{M}_{3}$ compounds. ${ }^{12}$ The structural data in Table 1 entail highquality X-ray data $\left(R_{1}<4 \%\right)$ for isomorphous forms (triclinic, $P \overline{1}$ ) of the three compounds at the same temperature $(100 \mathrm{~K})$, so as to warrant a reasonable comparison of the effect of the coinage metal on the molecular and supramolecular structures under normalized conditions. The triclinic $(P \overline{1})$ structure of $\mathbf{A g}_{3}$ at $100 \mathrm{~K}$ in Table 1 represents a polymorph of another structure of the same compound, which has been determined at room temperature ${ }^{10}$ to have a monoclinic $C 2 / c$ crystalline form for crystals obtained from hexane solutions. Though the structure of $\mathbf{A u}_{\mathbf{3}}$ had been determined by Bonati et al., ${ }^{13}$ the structural data were reported to be of low quality due to crystal deterioration; hence, a redetermination was warranted. We have recently reported the structure of $\mathbf{C u}_{3}$ at $100 \mathrm{~K}^{8 \mathrm{~b}}$ so the data for this compound are included here for comparison purposes.

The three complexes exist as trimers featuring ninemembered $\mathrm{M}_{3} \mathrm{~N}_{6}$ rings and two-coordinate metal sites (Figure 1). The $\mathrm{M}_{3} \mathrm{~N}_{6}$ moieties are essentially planar. For example, the mean and largest deviation from the $\mathrm{M}_{3} \mathrm{~N}_{6}$ plane for $\mathbf{C u}_{3}$, $\mathbf{A g}_{3}$, and $\mathbf{A u}_{3}$ are 0.06, $0.04 \AA, 0.10,0.05 \AA$, and 0.13, 0.07 $\AA$, respectively. The metal ions adopt a linear geometry with the silver(I) analogue showing the largest deviation from the ideal $180^{\circ}\left(\mathrm{N}-\mathrm{Ag}-\mathrm{N}\right.$ range $\left.172.0-177.7^{\circ}\right)$; it is also the system showing the shortest intertrimer $\mathrm{M} \cdots \mathrm{M}$ contacts.

The fundamental role of intertrimer bonding in the luminescent states of cyclic trimeric coinage metal complexes ${ }^{3-6,8}$ makes it essential to compare the supramolecular structures of the three $\mathbf{M}_{\mathbf{3}}$ isomorphous compounds. Figure 2 shows that all three compounds possess intertrimer $\mathrm{M} \cdots \mathrm{M}$ interactions, which are responsible for the resulting supramolecular extended structures. The $\mathbf{A g}_{3}$ complex forms zigzag chains

(10) Dias, H. V. R.; Polach, S. A.; Wang, Z. J. Fluorine Chem. 2000, 103, 163.

(11) Banditelli, G.; Bandini, A. L.; Bonati, F.; Goel, R. G.; Minghetti, G. Gazz. Chim. Ital. 1982, 112, 539.

(12) The CCDC Nos. 265271-265273 contain the supplementary crystallographic data for this paper. These data can be obtained free of charge via http://www.ccdc.cam.ac.uk/conts/retrieving.html (or from the Cambridge Crystallographic Data Centre (CCDC), 12 Union Road, Cambridge, CB2 1EZ, U.K.).

(13) Bovio, B.; Bonati, F.; Banditelli, G. Inorg. Chim. Acta 1984, 87, 25. 
Omary et al.

Table 1. Crystallographic Data for $\mathbf{M}_{3}$

\begin{tabular}{|c|c|c|c|c|}
\hline param & $\mathrm{Cu}_{3}$ & $\mathbf{A g}_{3}$ & $\mathbf{A u}_{3}$ & {$\left[\mathbf{A u}_{3}\right]_{2}:$ toluene } \\
\hline space gp & $P \overline{1}$ & $P \overline{1}$ & $P \overline{1}$ & $P \overline{1}$ \\
\hline$T / \mathrm{K}$ & 100 & 100 & 100 & 100 \\
\hline$a / \AA ̊$ & $9.1553(4)$ & $10.1597(6)$ & $9.0547(3)$ & $13.0872(5)$ \\
\hline$b / \AA ̊ ̊$ & $11.3906(5)$ & $10.5111(6)$ & $11.7744(4)$ & $13.7656(6)$ \\
\hline$c / \AA$ & $12.2324(5)$ & $11.6798(7)$ & $12.0997(5)$ & $16.6853(7)$ \\
\hline$\alpha / \operatorname{deg}$ & $66.407(1)$ & $74.034(1)$ & $65.971(1)$ & $94.657(1)$ \\
\hline$\beta / \mathrm{deg}$ & $74.453(1)$ & $74.724(1)$ & $80.683(1)$ & $103.268(1)$ \\
\hline$\gamma / \mathrm{deg}$ & $78.547(1)$ & 78.434(1) & $80.481(1)$ & $111.177(1)$ \\
\hline$V / \AA^{3}$ & $1120.21(8)$ & $1145.72(12)$ & $1155.56(7)$ & $2683.13(19)$ \\
\hline $\mathrm{R} 1, \mathrm{wR} 2[I>2 \sigma(I)]$ & $0.0356,0.0939$ & $0.0281,0.0620$ & $0.0204,0.0496$ & $0.0255,0.0691$ \\
\hline $\mathrm{R} 1$, wR2 (all data) & $0.0383,0.0968$ & $0.0345,0.0653$ & $0.0219,0.0502$ & $0.0289,0.0707$ \\
\hline $\mathrm{M}-\mathrm{N}(\mathrm{av}) / \AA$ & $1.859(2)$ & $2.091(3)$ & $1.996(4)$ & $2.003(4)$ \\
\hline $\mathrm{M}-\mathrm{N}($ range $) / \AA$ & $1.855(2)-1.863(2)$ & $2.081(3)-2.096(3)$ & $1.990(4)-2.003(4)$ & $1.986(4)-2.016(4)$ \\
\hline $\mathrm{N}-\mathrm{M}-\mathrm{N}(\mathrm{av}) / \mathrm{deg}$ & $178.46(10)$ & $174.81(12)$ & $179.60(16)$ & $176.51(18)$ \\
\hline $\mathrm{N}-\mathrm{M}-\mathrm{N}($ range $) / \mathrm{deg}$ & $178.37(10)-178.60(10)$ & $172.01(12)-177.69(13)$ & $179.45(16)-179.90(17)$ & $175.74(17)-177.11(18)$ \\
\hline $\mathrm{M} \cdots \mathrm{M}\left(\mathrm{av}\right.$ intra $\left.\mathbf{M}_{3}\right) / \AA$ & $3.2323(4)$ & $3.4968(4)$ & $3.3506(3)$ & $3.3440(3), 3.3311(3)$ \\
\hline $\mathrm{M} \cdots \mathrm{M}\left(\right.$ closest inter $\left.\mathbf{M}_{3}\right) / \AA$ & $3.813(1), 3.987(1)$ & $3.2037(4), 3.968(1)$ & $3.885(1), 3.956(1)$ & $3.2985(3), 3.542(1)$ \\
\hline
\end{tabular}

consisting of dimers of trimers that are loosely connected with one another whereas the extended structures of $\mathbf{C u}_{3}$ and
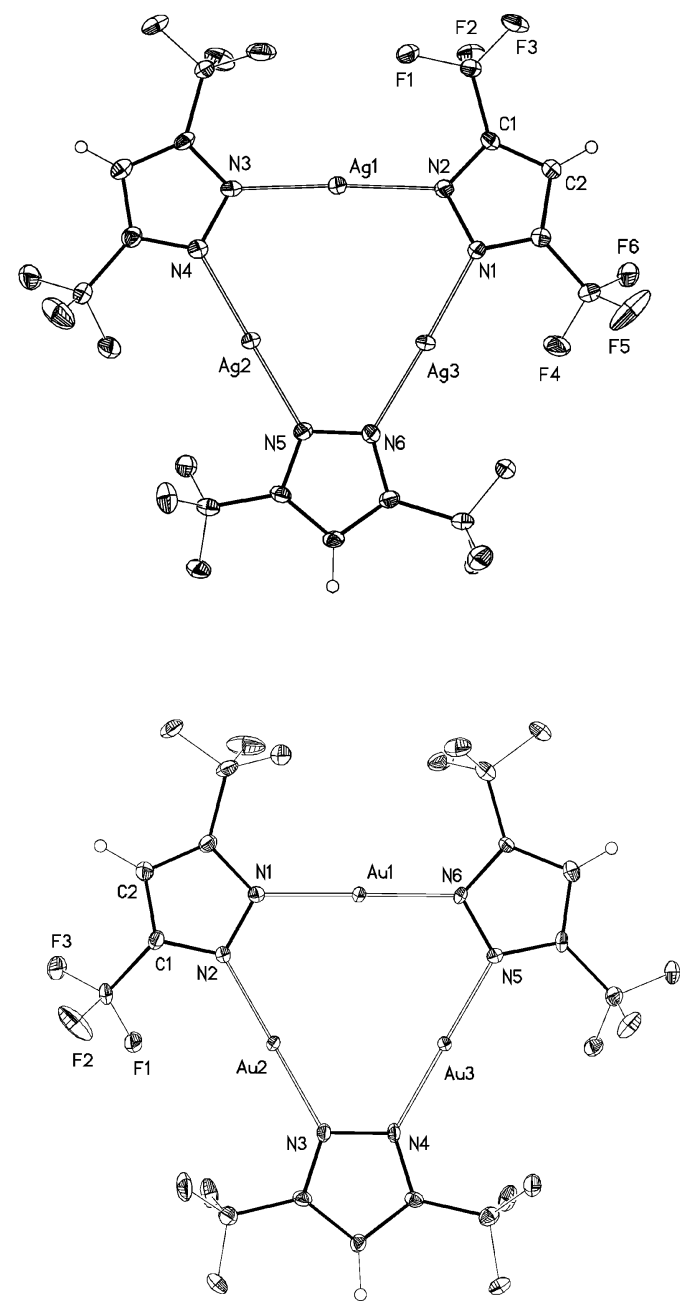

Figure 1. ORTEP diagrams showing the molecular structures of $\{[3,5-$ $\left.\left.\left(\mathrm{CF}_{3}\right)_{2} \mathrm{Pz}\right] \mathrm{Ag}\right\}_{3}$ (top) and $\left\{\left[3,5-\left(\mathrm{CF}_{3}\right)_{2} \mathrm{Pz}\right] \mathrm{Au}\right\}_{3}$ (bottom). Selected bond distances $(\AA)$ and angles $(\mathrm{deg})$ for $\left\{\left[3,5-\left(\mathrm{CF}_{3}\right)_{2} \mathrm{Pz}\right] \mathrm{Ag}\right\}_{3}: \mathrm{Ag}(1)-\mathrm{N}(2) 2.095-$ (3), $\mathrm{Ag}(1)-\mathrm{N}(3)$ 2.096(3), $\mathrm{Ag}(2)-\mathrm{N}(5)$ 2.081(3), $\mathrm{Ag}(2)-\mathrm{N}(4)$ 2.085(3), $\mathrm{Ag}(3)-\mathrm{N}(6) 2.094(3), \mathrm{Ag}(3)-\mathrm{N}(1) 2.095(3) ; \mathrm{N}(2)-\mathrm{Ag}(1)-\mathrm{N}(3)$ 172.01(12), $\mathrm{N}(5)-\mathrm{Ag}(2)-\mathrm{N}(4)$ 177.69(13), N(6) $-\mathrm{Ag}(3)-\mathrm{N}(1)$ 174.73(12). Selected bond distances $(\AA)$ and angles (deg) for $\left\{\left[3,5-\left(\mathrm{CF}_{3}\right)_{2} \mathrm{Pz}\right] \mathrm{Au}\right\}_{3}: \mathrm{Au}(1)-$ $\mathrm{N}(6) 1.990(4), \mathrm{Au}(1)-\mathrm{N}(1)$ 1.995(4), $\mathrm{Au}(2)-\mathrm{N}(3)$ 2.001(4), $\mathrm{Au}(2)-\mathrm{N}(2)$ 2.003(4), $\mathrm{Au}(3)-\mathrm{N}(4)$ 1.995(4), $\mathrm{Au}(3)-\mathrm{N}(5)$ 1.995(4); N(6)- $\mathrm{Au}(1)-\mathrm{N}(1)$ 179.45(16), N(3)-Au(2)-N(2) 179.46(16), N(4)-Au(3)-N(5) 179.90(17).
$\mathbf{A u}_{3}$ form chains of loosely connected trimers. The two closest $\mathbf{M} \cdots \mathbf{M}$ intertrimer distances in $\mathbf{C u}_{\mathbf{3}}, \mathbf{A} \mathbf{g}_{\mathbf{3}}$, and $\mathbf{A} \mathbf{u}_{\mathbf{3}}$ are 3.813(1), 3.987(1) $\AA$, 3.2037(4), 3.968(1) $\AA$, and 3.885(1), 3.956(1) А, respectively. It should be noted that theoretical studies suggest that unassisted metallophilic bonding should be accounted for even at rather long distances such as $4.5 \AA$, especially when the interaction involves multiple $\mathrm{M}$ centers ${ }^{14,15}$ see ref $8 \mathrm{~b}$ for further discussion. Overall, the number of pairwise $\mathrm{M} \cdots \mathrm{M}$ intertrimer interactions becomes greater upon proceeding from $\mathbf{C u}_{3} \rightarrow \mathbf{A g}_{3} \rightarrow$ $\mathbf{A u}_{3}$ (Figure 2), consistent with a trend of increasing relativistic effects, which are known to play a role in stabilizing metallophilic bonding. ${ }^{16}$ It is however surprising to find that the shortest intertrimer $\mathrm{M} \cdots \mathrm{M}$ distance is observed in $\mathbf{A g}_{3}$ (3.204 $\AA$ ) rather than in $\mathbf{C} \mathbf{u}_{3}$ (3.813 $\AA$ ) or $\mathbf{A u}_{3}(3.885 \AA$ ) despite the significantly larger covalent radius of $\mathrm{Ag}^{\mathrm{I}}$ compared to that of $\mathrm{Cu}^{\mathrm{I}}$ or $\mathrm{Au}^{\mathrm{I}}$ (vide infra).

Metallophilic bonding, especially when it involves multiple metal centers, is rather delicate and is only one component among other intermolecular forces (e.g., multipolar interactions, hydrogen bonding, $\pi$ stacking) that contribute to the stabilization of the packing in the solid state. ${ }^{17}$ This is manifested for the particular compounds herein by the observation of, for example, temperature-variable $\mathrm{M} \cdot \cdots \mathrm{M}$ interactions and unit cell dimensions and by the isolation of different polymorphic forms that differ primarily in intertrimer $\mathrm{M} \cdots \mathrm{M}$ packing upon different crystallization conditions (e.g., for $\mathbf{A g}_{3}$ ). For example, the room-temperature data reported previously ${ }^{10}$ for $\mathbf{C u}_{3}$ show intertrimer $\mathrm{Cu} \cdots \mathrm{Cu}$ separations of 3.879 and $3.893 \AA$ (cf. 3.813(1) and 3.987(1) $\AA$ at $100 \mathrm{~K}$ ) and a cell volume of $1199.8(2) \AA^{3}$ (vs 1120.21(8) $\AA^{3}$ at $\left.100 \mathrm{~K}\right)$. Coppens et al. have recently reported structural data for the same compound at $15 \mathrm{~K}$, which show intertrimer $\mathrm{Cu} \cdots \mathrm{Cu}$ distances of $3.787(1)$ and 4.018(1) $\AA$ and a cell volume of $1103.8(2) \AA^{3} .^{18}$ These collective data amount to a consistent trend for $\mathbf{C} \mathbf{u}_{3}$ in which cooling leads to a reduced cell volume with one intertrimer distance

(14) Poblet, J.-M.; Benard, M. Chem. Commun. 1998, 11, 1179.

(15) Pyykkö, P.; Runeberg, N.; Mendizabal, F. Chem.-Eur. J. 1997, 3, 1451.

(16) Pyykkö, P. Chem. Rev. 1997, 97, 599.

(17) Liau, R.-Y.; Mathieson, T.; Schier, A.; Berger, R. J.; Runeberg, N.; Schmidbaur, H. Z. Naturforsch. B 2002, 57, 881 . 


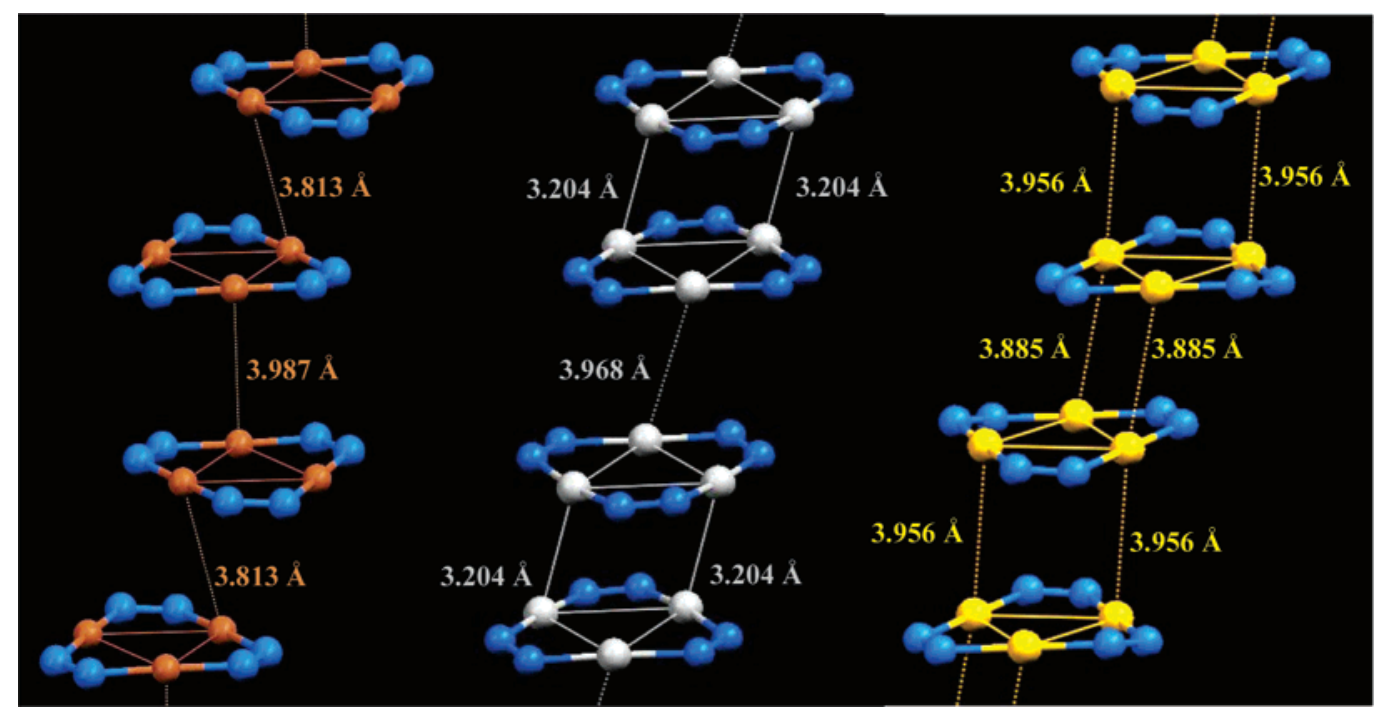

Figure 2. X-ray crystal structures of $\left\{\left[3,5-\left(\mathrm{CF}_{3}\right)_{2} \mathrm{Pz}\right] \mathrm{M}\right\}_{3}\left(\mathbf{M}_{3}\right)$ showing the packing of the $\mathrm{M}_{3} \mathrm{~N}_{6}$ metallacycles. $\mathrm{M}=\mathrm{Cu}, \mathrm{Ag}$, and $\mathrm{Au}$ from left to right, respectively.

becoming shorter while the other becoming longer. The $\mathbf{A u}_{3}$ unit cell occupies a larger volume at room temperature ${ }^{13}$ $\left(1223.1 \AA^{3}\right.$ vs $1155.56(7) \AA^{3}$ at $\left.100 \mathrm{~K}\right)$, and the shortest intertrimer $\mathrm{Au} \cdots \mathrm{Au}$ distance is $3.998 \AA$ at room temperature vs $3.888 \AA$ at $100 \mathrm{~K}$. The monoclinic form of $\mathbf{A g}_{3}$ exists as zigzag chains of alternating dimers of $\mathbf{A g}_{3}$ and isolated $\mathbf{A g}_{3}$ units. The room-temperature data of the monoclinic $\mathbf{A g}_{3}$ show that the intertrimer $\mathrm{Ag} \cdots \mathrm{Ag}$ separations within $\left[\mathbf{A g}_{3}\right]_{2}$ is $3.307 \AA$ whereas the closest $\mathrm{Ag} \cdots \mathrm{Ag}$ distance between $\left[\mathbf{A g}_{3}\right]_{2}$ and $\mathbf{A g}_{3}$ is $3.830 \AA$. Consistent with these crystallographic observations are results of quantum mechanical calculations we have carried out. Density functional theory (DFT) and second-order perturbation theory (MP2) calculations with relativistic effective core potentials performed on dimer of trimer models, $\left[\{\mathrm{PzM}\}_{3}\right]_{2}$, indicate an extremely soft potential surface for translational (parallel and perpendicular to the ring planes) trimer $\cdots$ trimer interactions. At a temperature of $100 \mathrm{~K}(\sim 3 / 2 R T \sim 0.3 \mathrm{kcal} / \mathrm{mol})$, for example, the DFT-derived (B3LYP/CSDZ*) potential energy curve for the separation of the $\mathrm{CuPz}$ units of $\left[\{\mathrm{PzCu}\}_{3}\right]_{2}$ suggests a range of inter-ring separations of ca. $\pm 0.3 \AA$ about the equilibrium distance as being thermally accessible.

The high quality of the X-ray data and the isomorphous structures of all three $\mathbf{M}_{3}$ compounds permit a direct comparison of the covalent radii of the three monovalent coinage metal ions. The average $\mathrm{M}-\mathrm{N}$ distances in $\mathbf{C u}_{3}, \mathbf{A g}_{3}$, and $\mathbf{A u}_{3}$ are 1.859(2), 2.091(3), 1.996(4) $\AA$, respectively (Table 1). Using the currently accepted covalent radius of $\mathrm{N}(0.75 \AA),{ }^{19}$ we thus estimate the covalent radius for twocoordinate $\mathrm{Cu}^{\mathrm{I}}, \mathrm{Ag}^{\mathrm{I}}$, and $\mathrm{Au}^{\mathrm{I}}$ as $1.11,1.34$, and $1.25 \AA$, respectively. These values are in excellent agreement with those proposed by Schmidbaur using two-coordinate coinage

(18) Vorontsov, I. I.; Kovalevsky, A. Yu.; Chen, Y.-S.; Graber, T.; Novozhilova, I. V.; Omary, M. A.;Coppens, P. Phys. Rev. Lett. 2005, 94, 193003.

(19) (a) Gordon, A. J.; Ford, R. A. The Chemist's Companion; Wiley: New York, 1972; p 85. (b) Winter, M. WebElements Periodic table (Professional Edition); accessible at http://www.webelements.com/ webelements/elements/text/N/radii.html. metal adducts of $\mathrm{Mes}_{3} \mathrm{P}\left(1.13,1.33\right.$, and $1.25 \AA$ for $\mathrm{Cu}^{\mathrm{I}}, \mathrm{Ag}^{\mathrm{I}}$, and $\mathrm{Au}^{\mathrm{I}}$, respectively). ${ }^{20}$ The excellent agreement occurs despite the fact that the $\mathrm{Cu}^{\mathrm{I}}$ complex in the Schmidbaur work, unlike the coinage metal trimers studied here, contains a solvent molecule and is not isomorphous with the $\mathrm{Ag}^{\mathrm{I}}$ and $\mathrm{Au}^{\mathrm{I}}$ complexes. On the other hand, while no intramolecular and intermolecular $\mathrm{M} \cdots \mathrm{M}$ interactions exist in the phosphine complexes, such interactions do exist here. However, the striking similarity with the values proposed by Schmidbaur suggests that the weak metallophilic interactions (3.2-4.0 $\AA$, Table 1) in $\mathbf{M}_{3}$ do not significantly affect the covalent radii of $\mathrm{M}^{\mathrm{I}}$. The comparison afforded by the present fluorinated $\mathbf{M}_{3}$ species would be more ambiguous in nonfluorinated $\mathbf{M}_{\mathbf{3}}$ trimers because the latter often exhibit rather short intertrimer separations $(2.8-3.0 \AA),{ }^{8 b}$ which can significantly influence the $\mathrm{M}-\mathrm{N}$ bonding.

Overall, a few structurally characterized trimeric coinage metal pyrazolates are known in the literature. However, the fluorinated $\mathrm{M}_{3}$ systems are very rare. We have recently reported several such copper(I) adducts involving the fluorinated ligands $\left[3-\left(\mathrm{CF}_{3}\right) \mathrm{Pz}\right]^{-},\left[3-\left(\mathrm{CF}_{3}\right), 5-(\mathrm{Me}) \mathrm{Pz}\right]^{-}$, and $\left[3-\left(\mathrm{CF}_{3}\right), 5-(\mathrm{Ph}) \mathrm{Pz}\right]^{-}{ }^{-8 b}$ Other copper(I) pyrazolates with structural data include $\left\{\left[3,5-(\mathrm{Me})_{2}, 4-\left(\mathrm{NO}_{2}\right) \mathrm{Pz}\right] \mathrm{Cu}\right\}_{3},{ }^{21}\{[2-$ (3-Pz)Py $] \mathrm{Cu}_{3},{ }^{22}\left\{[2-(3-\mathrm{Pz})-6-\mathrm{Me}-\mathrm{Py}] \mathrm{Cu}_{3},{ }^{23}\left\{\left[3,5-(\mathrm{Ph})_{2} \mathrm{Pz}\right]-\right.\right.$ $\mathrm{Cu}_{3},{ }^{24}\left\{\left[3,5-(\mathrm{Me})_{2} \mathrm{Pz}\right] \mathrm{Cu}\right\}_{3},{ }^{25}\left\{\left[3,4,5-(\mathrm{Me})_{4} \mathrm{Pz}\right] \mathrm{Cu}\right\}_{3},{ }^{26}$ and $\left\{\left[3,5-(i-\mathrm{Pr})_{2} \mathrm{Pz}\right] \mathrm{Cu}\right\}_{3}{ }^{8 \mathrm{~b}, 27} \mathrm{Crystallographic} \mathrm{data} \mathrm{for} \mathrm{the} \mathrm{silver-}$

(20) Bayler, A.; Schier, A.; Bowmaker, G. A.; Schmidbaur, H. J. Am. Chem. Soc. 1996, 118, 7006 .

(21) Ardizzoia, G. A.; Cenini, S.; La Monica, G.; Masciocchi, N.; Maspero, A.; Moret, M. Inorg. Chem. 1998, 37, 4284.

(22) Singh, K.; Long, J. R.; Stavropoulos, P. J. Am. Chem. Soc. 1997, 119 , 2942.

(23) Singh, K.; Long, J. R.; Stavropoulos, P. Inorg. Chem. 1998, 37, 1073

(24) Raptis, R. G.; Fackler, J. P., Jr. Inorg. Chem. 1988, 27, 4179.

(25) Ehlert, M. K.; Rettig, S. J.; Storr, A.; Thompson, R. C.; Trotter, J. Can. J. Chem. 1990, 68, 1444.

(26) Ehlert, M. K.; Rettig, S. J.; Storr, A.; Thompson, R. C.; Trotter, J. Can. J. Chem. 1992, 70, 2161.

(27) Fujisawa, K.; Ishikawa, Y.; Miyashita, Y.; Okamoto, K.-I. Chem. Lett. 2004, 33, 66 . 
(I) adducts $\{[2-(3-\mathrm{Pz}) \mathrm{Py}] \mathrm{Ag}\}_{3},{ }^{22}\left\{\left[3,5-(\mathrm{Ph})_{2} \mathrm{Pz}\right] \mathrm{Ag}\right\}_{3},{ }^{28,29}\{-$ $[\mathrm{Pz}] \mathrm{Ag}\}_{3},{ }^{30}$ and $\left\{\left[3,5-\left(i-\mathrm{PrSCH}_{2}\right)_{2} \mathrm{Pz}\right] \mathrm{Ag}\right\}_{3}{ }^{31}$ and the gold(I) adducts $\left\{\left[3,5-(\mathrm{Ph})_{2} \mathrm{Pz}\right] \mathrm{Au}\right\}_{3},{ }^{28}\{[\mathrm{Pz}] \mathrm{Au}\}_{3},{ }^{32}\left\{\left[3,5-(\mathrm{Me})_{2}, 4-\right.\right.$ $(\mathrm{Oct}) \mathrm{Pz}] \mathrm{Au}\}_{3},{ }^{33}\{[4-(\mathrm{Me}) \mathrm{Pz}] \mathrm{Au}\}_{3},{ }^{32}\{[3-(\mathrm{Me}), 5-(\mathrm{Ph}) \mathrm{Pz}]-$ $\mathrm{Au}\}_{3},{ }^{32}$ and $\left\{\left[3,5-(4-\mathrm{MeOPh})_{2} \mathrm{Pz}\right] \mathrm{Au}\right\}_{3}{ }^{34}$ have also been reported. Among these, $\{[2-(3-\mathrm{Pz}) \mathrm{Py}] \mathrm{Cu}\}_{3}(2.905 \AA),{ }^{22}\{-$ $\left.\left[3,5-(\mathrm{Ph})_{2} \mathrm{Pz}\right] \mathrm{Ag}\right\}_{3}(2.971 \AA),{ }^{29}$ and $\{[\mathrm{Pz}] \mathrm{Au}\}_{3}(3.160 \AA)^{32}$ have the shortest intertrimer $\mathrm{M} \cdots \mathrm{M}$ contacts for each respective coinage metal.

Apart from the $\mathbf{M}_{\mathbf{3}}$ complexes described in this article, the $\left\{\left[3,5-(\mathrm{Ph})_{2} \mathrm{Pz}\right] \mathrm{M}\right\}_{3}$ adducts $^{24,28,29}$ represent the only other isoleptic coinage metal pyrazolate series with known solidstate structural data. However, unlike the $\mathbf{M}_{3}$ series, the $\{-$ $\left.\left[3,5-(\mathrm{Ph})_{2} \mathrm{Pz}\right] \mathrm{M}\right\}_{3}$ series does not have isomorphous complexes to allow a meaningful comparison of the structural data upon changing the coinage metal. The copper complex $\left\{\left[3,5-(\mathrm{Ph})_{2} \mathrm{Pz}\right] \mathrm{Cu}\right\}_{3}{ }^{24}$ shows severe distortions from planarity with an average intratrimer $\mathrm{Cu} \cdot \cdots \mathrm{Cu}$ separation of 3.339(1) $\AA$. The intertrimer $\mathrm{Cu} \cdots \mathrm{Cu}$ distances are very long (the closest is $5.40 \AA$ ). The average $\mathrm{Cu}-\mathrm{N}$ distance (2.081(7) $\AA$ ) is almost as long as the average $\mathrm{Ag}-\mathrm{N}$ distance (2.088(4) $\AA$ ) in $\left\{\left[3,5-(\mathrm{Ph})_{2} \mathrm{Pz}\right] \mathrm{Ag}\right\}_{3} .{ }^{29}$ Interestingly, while one form of $\left\{\left[3,5-(\mathrm{Ph})_{2} \mathrm{Pz}\right] \mathrm{Ag}\right\}_{3}$ crystals obtained from $\mathrm{CH}_{2} \mathrm{Cl}_{2}$ solution contains dimers of trimers with one short $\mathrm{Ag} \cdots \mathrm{Ag}$ contact at 2.9712(14) $\AA,{ }^{29}$ crystals of the same compound obtained from $\mathrm{THF} / \mathrm{Et}_{2} \mathrm{O}$ give rise to another polymorph in which the trimers are well separated with no close $\mathrm{Ag} \cdots$ Ag contacts. ${ }^{28}$ For comparison, the intertrimer $\mathrm{Au} \cdots \mathrm{Au}$ separation of the planar gold analogue $\left\{\left[3,5-(\mathrm{Ph})_{2} \mathrm{Pz}\right] \mathrm{Au}\right\}_{3}$ is very long $(7.567$ A).$^{28}$ Apart from the trimers, a tetramer $\left\{\left[3,5-(\mathrm{Ph})_{2} \mathrm{Pz}\right] \mathrm{Cu}\right\}_{4}{ }_{4}^{35}$ and a hexamer $\left\{\left[3,5-(\mathrm{Ph})_{2} \mathrm{Pz}\right] \mathrm{Au}\right\}{ }^{28}$ based on the same ligand are also known.

Photophysical Properties. The remarkable photophysical behavior of single crystals of $\mathbf{M}_{3}$ is illustrated in Figure 3. Crystals of each compound exhibit striking luminescence thermochromism, the most dramatic of which is for $\mathbf{A} \mathbf{u}_{3}$ whose emission color can be coarse-tuned from the UV region $\left(\lambda_{\max } \sim 365 \mathrm{~nm}\right)$ at $4 \mathrm{~K}$ to green $\left(\lambda_{\max } \sim 535 \mathrm{~nm}\right)$ upon heating toward $77 \mathrm{~K}$ and then to orange $\left(\lambda_{\max } \sim 660\right.$ $\mathrm{nm}$ ) upon further heating toward room temperature. $\mathbf{C u}_{3}$ exhibits yellow and red emission bands while $\mathbf{A g}_{3}$ exhibits UV and blue emission bands. In all cases, the lower energy bands become more dominant upon heating to higher temperatures. The emission bands of all three compounds represent phosphorescence with lifetimes on the order of 10$100 \mu \mathrm{s}$, they are unstructured in profile, and they possess a substantial energy gap between the corresponding emission

(28) Murray, H. H.; Raptis, R. G.; Fackler, J. P., Jr. Inorg. Chem. 1988, $27,26-33$.

(29) Mohamed, A. A.; Perez, L. M.; Fackler, J. P., Jr. Inorg. Chim. Acta 2005, 358, 1657

(30) Masciocchi, N.; Moret, M.; Cairati, P.; Sironi, A.; Ardizzoia, G. A.; La Monica, G. J. Am. Chem. Soc. 1994, 116, 7668.

(31) Meyer, F.; Jacobi, A.; Zsolnai, L. Chem. Ber./Recueil 1997, 130, 1441.

(32) Yang, G.; Raptis, R. G. Inorg. Chem. 2003, 42, 261

(33) Kim, S. J.; Kang, S. K.; Park, K.-M.; Zin, W.-C.; Choi, M.-G.; Kim, K. Chem. Mater. 1998, 10, 1889.

(34) Barbera, J.; Elduque, A.; Gimenez, R.; Lahoz, F. J.; Lopez, J. A.; Oro, L. A.; Serrano, J. L. Inorg. Chem. 1998, 37, 2960.

(35) Ardizzoia, G. A.; Cenini, S.; La Monica, G.; Masciocchi, N.; Moret, M. Inorg. Chem. 1994, 33, 1458.

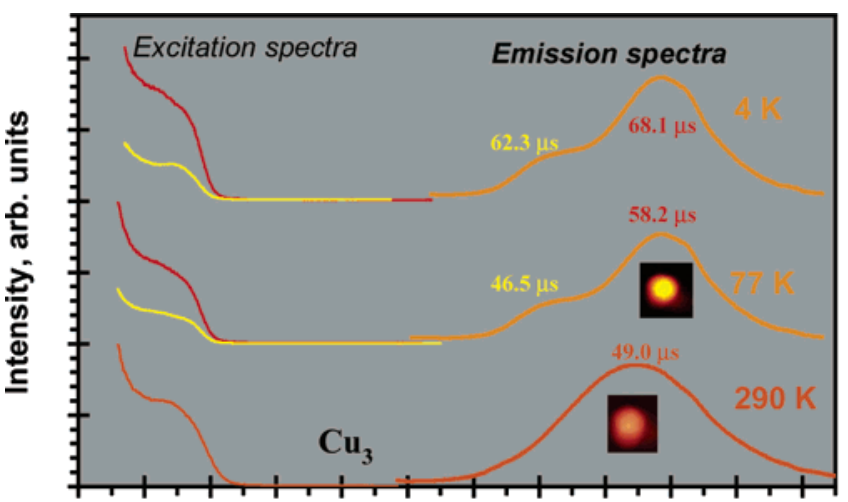

$\begin{array}{llllllllllll}225 & 275 & 325 & 375 & 425 & 475 & 525 & 575 & 625 & 675 & 725 & 775\end{array}$
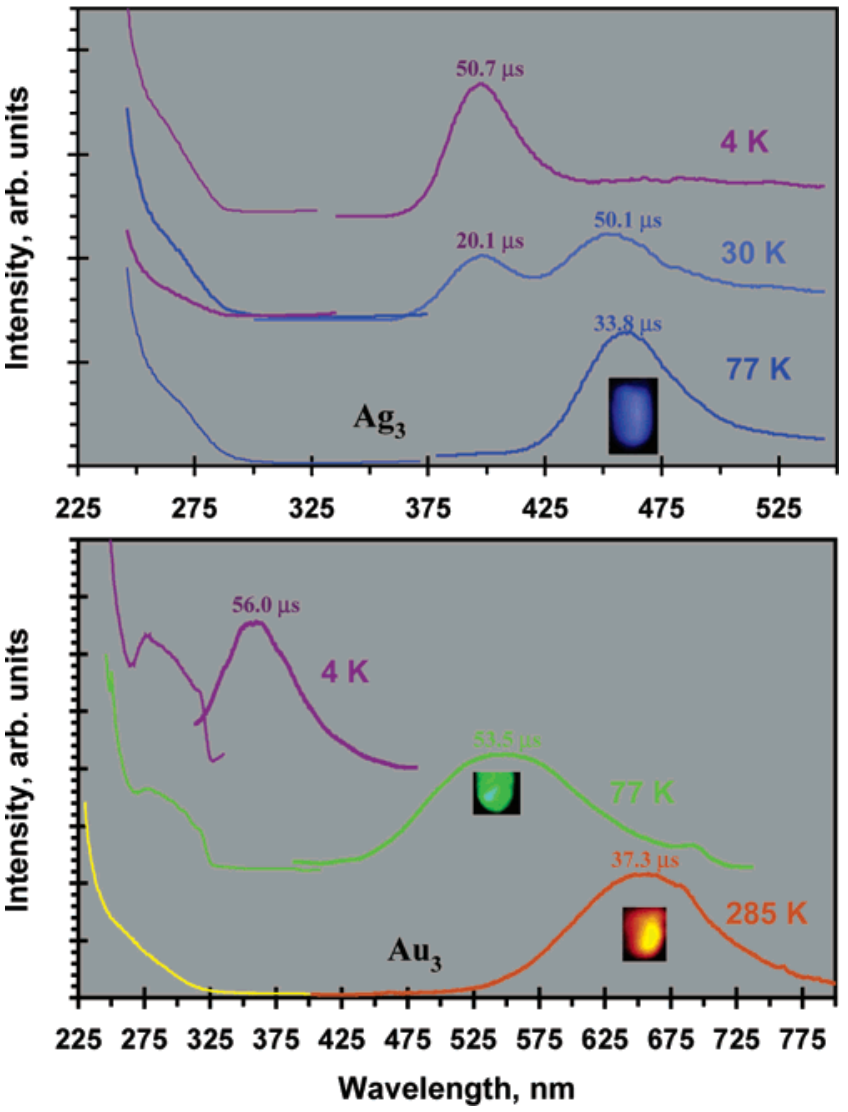

Figure 3. Photoluminescence spectra of single crystals of $\mathbf{M}_{\mathbf{3}}$ versus temperature. Lifetimes are noted for each band and have errors of $<5 \%$. Photographs are shown for colorless crystals packed in Suprasil quartz tubes while being exposed to UV light at room temperature or immediately after removal from a liquid-nitrogen bath $(77 \mathrm{~K})$.

and excitation maxima (Figure 3). UV excitations at very short wavelengths $(\lambda \leq 290 \mathrm{~nm})$ are required to generate the visible emissions in all three complexes (Figure 3). Though these excitation wavelengths are rather short, they are significantly red shifted from the major solution absorption maxima. Dilute solutions of $\mathbf{C u}_{3}, \mathbf{A g}_{3}$, and $\mathbf{A u}_{3}$ exhibit electronic absorption spectra (Figure 4) with major peaks between 212 and $230 \mathrm{~nm}\left(\epsilon=7.11 \times 10^{3}, 7.02 \times 10^{4}\right.$, and $2.12 \times 10^{3} \mathrm{M}^{-1} \mathrm{~cm}^{-1}$, respectively, in HPLC-grade cyclohexane). The high molar absorptivities and energies suggest that these absorption bands likely represent spin-allowed transitions to excited states that have a charge-transfer character. Results of DFT calculations for $\{\mathrm{PzM}\}_{3}$ models suggest that the lowest energy absorption involves a transition 

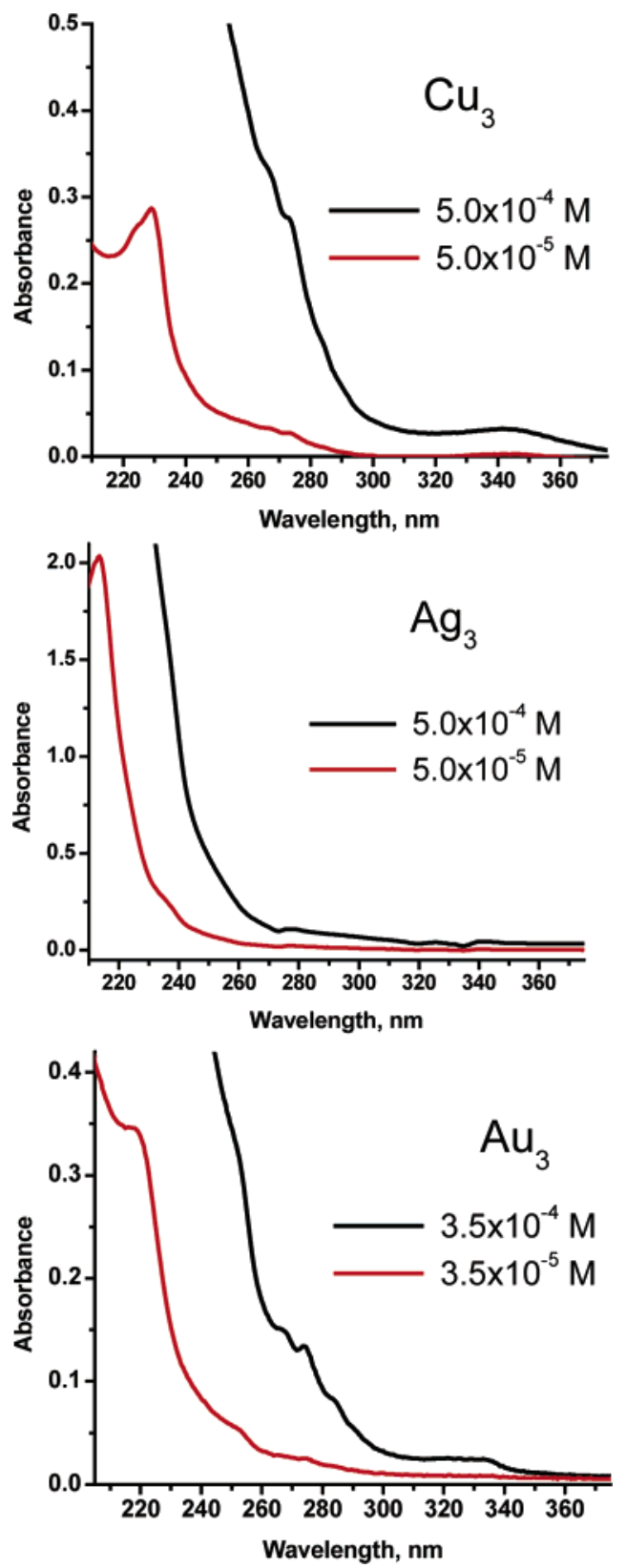

Figure 4. Absorption spectra of solutions of $\mathbf{C u}_{3}, \mathbf{A g}_{3}$, and $\mathbf{A u}_{3}$ in cyclohexane.

between a filled orbital with a strong ligand character to a vacant orbital with a strong metal character showing intratrimer $\mathrm{M}-\mathrm{M} \sigma_{(n+1) \mathrm{s}}$ bonding. Figure 5a illustrates this for $\{\mathrm{PzCu}\}_{3}$; similar contours were obtained for the analogous $\mathrm{Ag}$ and $\mathrm{Au}$ monomers of trimers. On the basis of the above spectroscopic and computational results, we assign the major absorption bands of $\mathbf{M}_{3}$ solutions to ${ }^{1} \mathrm{LMMCT}$ excited states. However, weak solution absorption features, which correspond to the crystals' phosphorescence excitation spectra, are discernible at longer wavelengths (Figure 4). The extinction coefficient for these weak absorption features are

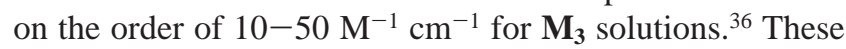
observations suggest that the lowest energy features in the luminescence excitation spectra of the single crystals likely

(36) The exact $\epsilon$ values are concentration dependent due to a non-Beer's law behavior. represent spin-forbidden transitions; hence, the large energy difference from the corresponding phosphorescence energies represents an energy gap between spin-forbidden transitions. The underlying huge Stokes' shifts and the overall spectral observations above indicate rather significant excited-state distortions for the phosphorescent states of the three compounds. Zigzag chains of coinage metal pyrazolate trimers contain adjacent $\mathrm{d}^{10}$ centers, which in principle should lead to multiple excitation possibilities between antibonding to bonding frontier orbitals. Such excitations would result in enhanced $\mathrm{M}-\mathrm{M}$ bonding in the excited state to explain the large excited-state distortion.

To gain specific insights about the structure of the excited state, density functional and Møller-Plesset calculations were performed on $\{\mathrm{PzM}\}_{3}$ and $\left[\{\mathrm{PzM}\}_{3}\right]_{2}(\mathrm{M}=\mathrm{Cu}, \mathrm{Ag}$, $\mathrm{Au})$. The results of these calculations do indicate that the excited-state distortion mode is enhanced $\mathrm{M}-\mathrm{M}$ bonding following photon absorption. Figure $5 \mathrm{~b}, \mathrm{c}$ shows that the lowest energy excitation in $*\left[\{\mathrm{PzCu}\}_{3}\right]_{2}$ and $*\left[\{\mathrm{PzAu}\}_{3}\right]_{2}$ dimer of trimers models involves an intertrimer transition to a molecular orbital with $\mathrm{M}-\mathrm{M}$ bonding. Similar frontier orbitals are found for the analogous silver pyrazolate dimer of trimers. Higher energy excited states in $\left[\{\mathrm{PzM}\}_{3}\right]_{2}$ models and the lowest energy excited state of $\{\mathrm{PzM}\}_{3}$ models involve intratrimer $\mathrm{M}-\mathrm{M}$ bonding. The HOMO-LUMO transitions shown in Figure 5 and a variety of similar transitions between frontier orbitals lead to singlet and triplet excited states that are subject to spin-orbit splitting and configuration mixing, leading to multiple excited states with enhanced $\mathrm{M}-\mathrm{M}$ bonding that may decay radiatively to the weakly bound ground state.

Figure 6 shows a qualitative model of the photophysics in a compound with three phosphorescent ${ }^{3} \mathrm{MM}$ states, such as the case in $\mathbf{A} \mathbf{u}_{3}$. At high enough temperatures (e.g., room temperature), relaxation to the lowest emissive state takes place and one emission band is seen (orange for $\mathbf{A} \mathbf{u}_{3}$ ). Such a relaxation may be hindered at low temperatures, leading to possible emissions from higher lying $\mathrm{M}-\mathrm{M}$ bound states at cryogenic temperatures. Internal conversion between different phosphorescent states is possible upon progressive heating. For the $\mathbf{A u}_{3}$ complex, for example, such internal conversion processes lead to the phosphorescence color change from $\mathrm{UV} \rightarrow$ green upon heating in the $4-77 \mathrm{~K}$ range and from green $\rightarrow$ orange upon heating between $77 \mathrm{~K}$ and room temperature. Similar models involving only two bound phosphorescent states can explain the observed luminescence thermochromism in $\mathbf{A g}_{3}$ and $\mathbf{C u}_{3}$. The photophysical data for $\mathbf{C u}_{3}$, however, suggest a poor efficiency of the internal conversion from the yellow to the red component in the cold temperature range, as cooling to $4 \mathrm{~K}$ does not isolate the yellow component or significantly increase its relative intensity from what it was at $77 \mathrm{~K}$; this result was reproduced multiple times. Unlike $\mathbf{A u}_{3}$ and $\mathbf{C u}_{3}$, crystals of $\mathbf{A g}_{3}$ do not exhibit detectable emissions at room temperature. Nevertheless, the UV $\rightarrow$ blue internal conversion in $\mathbf{A g}_{3}$ is rather efficient even at very cold temperatures. A sudden reversal of the relative intensity occurs upon fine changes in temperature around $30 \mathrm{~K}$, above which the blue emission 

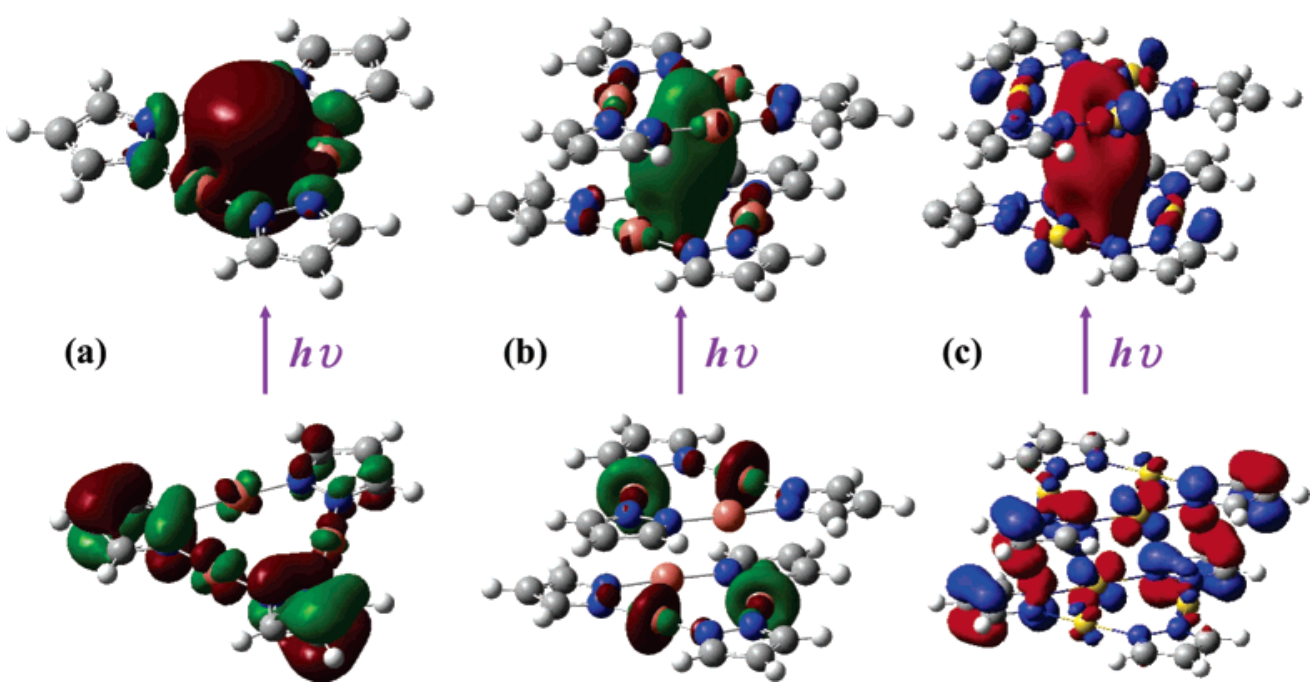

Figure 5. Contours of the two Kohn-Sham orbitals involved in the lowest energy excitation of (a) $\{\mathrm{PzCu}\}_{3}$, (b) $\left[\{\mathrm{PzCu}\}_{3}\right]_{2}$, and (c) $\left[\{\mathrm{PzAu}\}_{3}\right]_{2}$. Similar contours were obtained for the Ag monomer-of-trimer and dimer-of-trimer analogues.

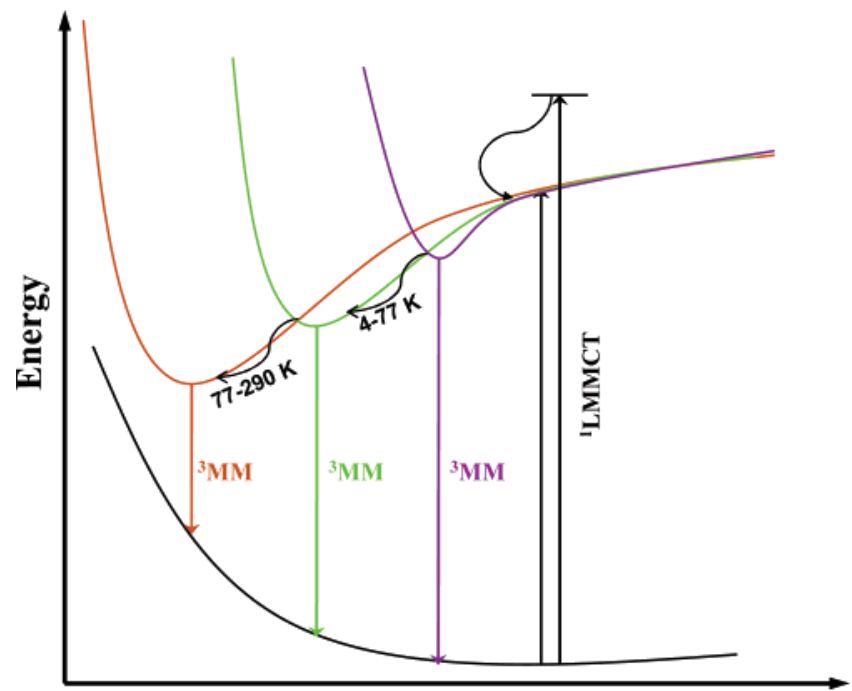

Distortion coordinate

Figure 6. Qualitative description of the photophysical processes in $\mathbf{A u}_{3}$. The same principles are valid for $\mathbf{A g}_{3}$ and $\mathbf{C u}_{3}$, for which two instead of three ${ }^{3} \mathrm{MM}$ emitting states are involved.

becomes the dominant band. Though one would be tempted to invoke a structural phase transition to be a possible cause for such a luminescence thermochromic change, we rule out this possibility because the overall temperature-dependent luminescence data for $\mathbf{A g}_{3}$ and also the $\mathrm{Cu}$ and $\mathrm{Au}$ analogues show that the excitation profiles are essentially temperature independent, unlike the emission data. Since a phase transition is a ground-state behavior, its occurrence should lead to changes in ground-state properties such as absorption or excitation energies. The crystallographic data discussed above do not entail any space group changes upon temperature variations for the same crystal of any of the three compounds. While these structural data do suggest temperature-dependent changes in intertrimer $\mathrm{M} \cdots \mathrm{M}$ separations and overall contractions in the unit cell volumes upon cooling (vide supra), we rule out the possibility that intermetal contractions are responsible for the dramatic luminescence thermochromic changes in crystals of the $\mathbf{M}_{3}$ complexes herein. Although such effects are known for other closed-shell coordination compounds that show anisotropic M $\cdots$ M packing in the solid state, ${ }^{37}$ the major consequence of such thermal compressions is usually ${ }^{37}$ a gradual red shift in the emission maximum of one band upon cooling. In contrast, the luminescence data here for $\mathbf{M}_{\mathbf{3}}$ crystals clearly show that the temperaturedependent changes are instead manifested by appearance of new higher energy emissions concomitant with the disappearance of the lower energy bands upon cooling while each of the bands exhibits insignificant changes in energy. Thus, the model we propose in Figure 6 to explain the excitedstate structure and luminescence thermochromism in $\mathbf{M}_{3}$ crystals entails photophysical transformations between different $\mathrm{M}-\mathrm{M}$ bound excited states as opposed to changes in either the ground state or within a given emitting state. We have proposed a similar explanation for a variety of $\{[3-$ (R),5-( $\left.\left.\left.\mathrm{R}^{\prime}\right) \mathrm{Pz}\right] \mathrm{Cu}\right\}_{3}$ complexes, which also undergo significant luminescence thermochromic changes. ${ }^{8}$ Recently, Coppens et al. reported an elegant study in which the crystal structure of the phosphorescent excited state of $\mathbf{C u}_{3}$ at $15 \mathrm{~K}$ was directly measured by time-resolved X-ray diffraction. ${ }^{18}$ The results showed that the trimeric molecules diffused in the solid state following photon absorption, leading to a series of dimers of trimers in which one of the intermolecular $\mathrm{Cu}-$ $\mathrm{Cu}$ distances is reduced by $0.56 \AA$, from 4.018(1) $\AA$ to 3.46(1) $\AA$, while the interplanar spacing between the two bound trimers is reduced by $0.65 \AA !^{18}$ These structural results are clearly consistent with our spectroscopic and theoretical interpretations here and in ref 8 about the excited-state structure of trinuclear coinage metal pyrazolates while specific insights regarding the excited-state structural changes that accompany the drastic luminescence thermochromism

(37) See, for example: (a) Gliemann, G.; Yersin, H. Struct. Bonding 1985, 62, 87. (b) Connick, W. B.; Henling, L. M.; Marsh, R. E.; Gray, H. B. Inorg. Chem. 1996, 35, 6261. (c) Nagasundaram, N.; Roper, G.; Biscoe, J.; Chai, J. W.; Patterson, H. H.; Blom, N.; Ludi, A. Inorg. Chem. 1986, 25, 2947. (d) Burini, A.; Bravi, R.; Fackler, J. P., Jr.; Galassi, R.; Grant, T. A.; Omary. M. A.; Pietroni, B. R.; Staples, R. J. Inorg. Chem. 2000, 39, 3158. (e) Assefa, Z.; G. McBurnett, B. G.; Staples, R. J.; Fackler, J. P., Jr.; Assman, B.; Angermaier, K.; Schmidbaur, H. Inorg. Chem. 1995, 34, 75. 


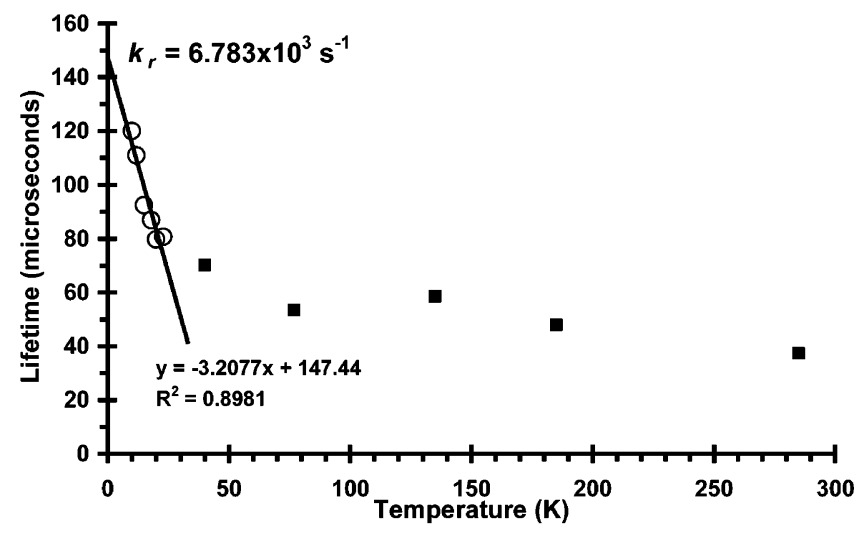

Figure 7. Selected temperature-dependent lifetime data for the green emission band of $\mathbf{A} \mathbf{u}_{3}$.

in such compounds must await time-resolve diffraction studies of the same crystal at different temperatures.

The observation of multiple phosphorescence bands in a pure single crystal of the same molecular compound is contradictory to a common rule of thumb in photophysics known as "Kasha's rule", by which higher lying states of the same spin multiplicity are presumed to cascade to the lowest energy state within that spin manifold by a series of internal conversions. ${ }^{38}$ However, numerous exceptions to this rule have been reported. Relevant examples include the multiple phosphorescence bands in $* \mathrm{Hg}_{n}$ excimeric clusters, ${ }^{39}$ copper halide clusters, ${ }^{40}$ and ruthenium(II) complexes ${ }^{41}$ and also multiple fluorescence bands in excimer-forming aromatic hydrocarbons such as pyrene. ${ }^{42}$

We have carried out temperature-dependent lifetime studies for crystals of the three compounds on the basis of the assignment discussed above. The data illustrate a large increase in the lifetime values for each band upon cooling. This increase is especially substantial in the coldest temperature range $(4-25 \mathrm{~K})$ at which a very sharp slope is seen due to annihilation of the nonradiative decay rate at such temperatures. Extrapolation of this slope to $0 \mathrm{~K}$ for the dominant bands in this temperature range gives rise to a radiative decay rate constant, $k_{\mathrm{r}}$, of $1.45 \times 10^{4}, 1.73 \times 10^{4}$, and $1.68 \times 10^{4} \mathrm{~s}^{-1}$ for $\mathbf{C u}_{3}(\sim 660 \mathrm{~nm}), \mathbf{A g}_{3}(\sim 395 \mathrm{~nm})$, and $\mathbf{A} \mathbf{u}_{3}(365 \mathrm{~nm})$, respectively. Assuming unity intersystem crossing, these values and the lifetimes at $4 \mathrm{~K}$ give rise to phosphorescence quantum yields of $98.8 \%, 87.7 \%$, and 94.2\% for crystals of $\mathbf{C u}_{3}, \mathbf{A g}_{3}$, and $\mathbf{A u}_{3}$, respectively. These values drop slightly upon heating within the same linear range of $\sim 4-25 \mathrm{~K}$. A similar treatment was possible for the green emission band of $\mathbf{A} \mathbf{u}_{\mathbf{3}}$ because it also appears in the cold temperature range, starting at $10 \mathrm{~K}$, in addition to the $365 \mathrm{~nm}$ band. Figure 7 serves to illustrate the treatment of the temperature-dependent lifetime data in this work by plotting the data for the green emission band of $\mathbf{A u}_{3}$. The sharp slope in the coldest temperature range $(10-25 \mathrm{~K})$ gives rise to $k_{\mathrm{r}}=6.78 \times 10^{3} \mathrm{~s}^{-1}$ and a corresponding quantum yield of $81.3 \%$ at $10 \mathrm{~K}$. At higher temperatures, the higherenergy excited states are depopulated via internal conversion to lower energy phosphorescent states and the kinetic treatment becomes more complicated, especially due to possible existence of thermal equilibration between spinorbit states. ${ }^{41}$

The trend in the lowest energy emission band (maximum at $15.1 \times 10^{3}, 21.7 \times 10^{3}$, and $15.0 \times 10^{3} \mathrm{~cm}^{-1}$ for $\mathbf{C u}_{3}$, $\mathbf{A g}_{3}$, and $\mathbf{A u}_{3}$, respectively) may be traced to the energy of the lowest triplet state (relative to the singlet ground state) of the three monovalent coinage metal ions, $E\left({ }^{3} \mathrm{D}\right)=22.6$ $\times 10^{3}, 40.6 \times 10^{3}$, and $18.5 \times 10^{3} \mathrm{~cm}^{-1}$ for $\mathrm{Cu}^{\mathrm{I}}, \mathrm{Ag}^{\mathrm{I}}$, and $\mathrm{Au}^{\mathrm{I}}$, respectively. ${ }^{43}$ However, other factors must be considered for a rigorous comparison among the three coinage metal complexes (e.g., spin-orbit splitting, ligand-field splitting, and extent of excited-state interactions). Quantification of these factors warrants further spectroscopic and theoretical studies, which are underway for $\mathbf{M}_{\mathbf{3}}$ and other coinage metal multinuclear complexes.

Acid-Base Properties. The last aspect considered in the comparison of coinage metal pyrazolate trimers involves their acid-base behavior. Figures 8 and 9 show the calculated molecular electrostatic potentials (MEPs) and elucidate the role of both the metal and $\mathrm{R}$ substituents on the acid-base behavior of $\left\{\left[3,5-(\mathrm{R})_{2} \mathrm{Pz}\right] \mathrm{M}\right\}_{3}$ models. The results suggest that complexes with $\mathrm{R}=\mathrm{H}$ or $\mathrm{Me}$ are bases with the relative basicity order $\mathrm{Ag} \ll \mathrm{Cu}<\mathrm{Au}$. However, fluorination of the pyrazolates makes even the Au trimer acidic, suggesting that the ligand effect can countermand the metal-based acidity/ basicity in these complexes. Ongoing experimental efforts in our laboratories indicate the formation of binary acidbase compounds with aromatic molecules using the MEP predictions as a guide. An example is shown in Figure 10 for an adduct that formed between $\mathbf{A u}_{3}$ and toluene. This was isolated from a toluene solution of $\mathbf{A} \mathbf{u}_{3}$. The supramolecular structure of this adduct entails infinite chains with each chain consisting of alternating toluene and $\left[\mathrm{Au}_{3}\right]_{2}$ dimer-

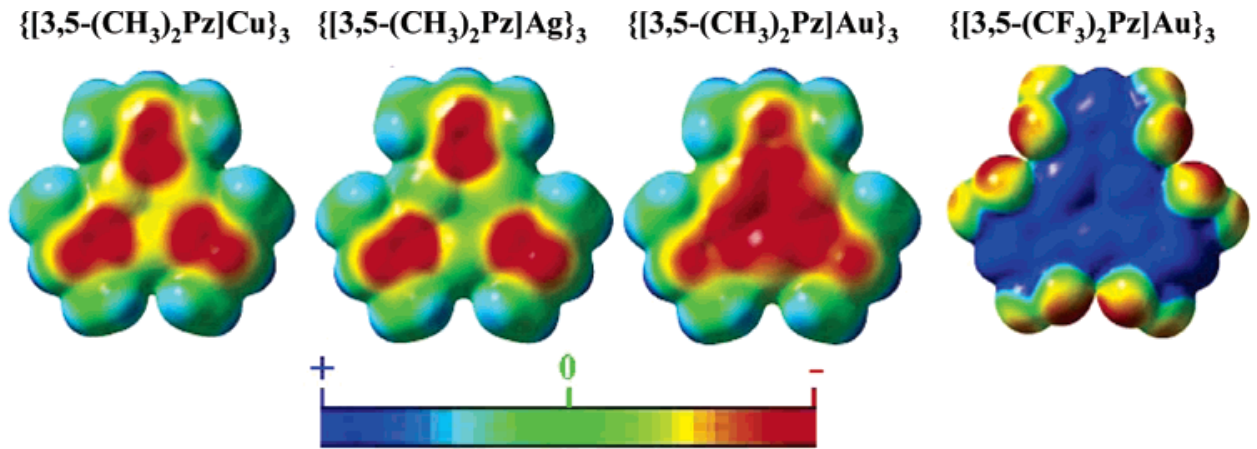

Figure 8. DFT-derived molecular electrostatic potentials (MEP) mapped onto the electron density surfaces of selected $\left\{\left[3,5-(\mathrm{R})_{2} \mathrm{Pz}\right] \mathrm{M}\right\}_{3}$ models. 


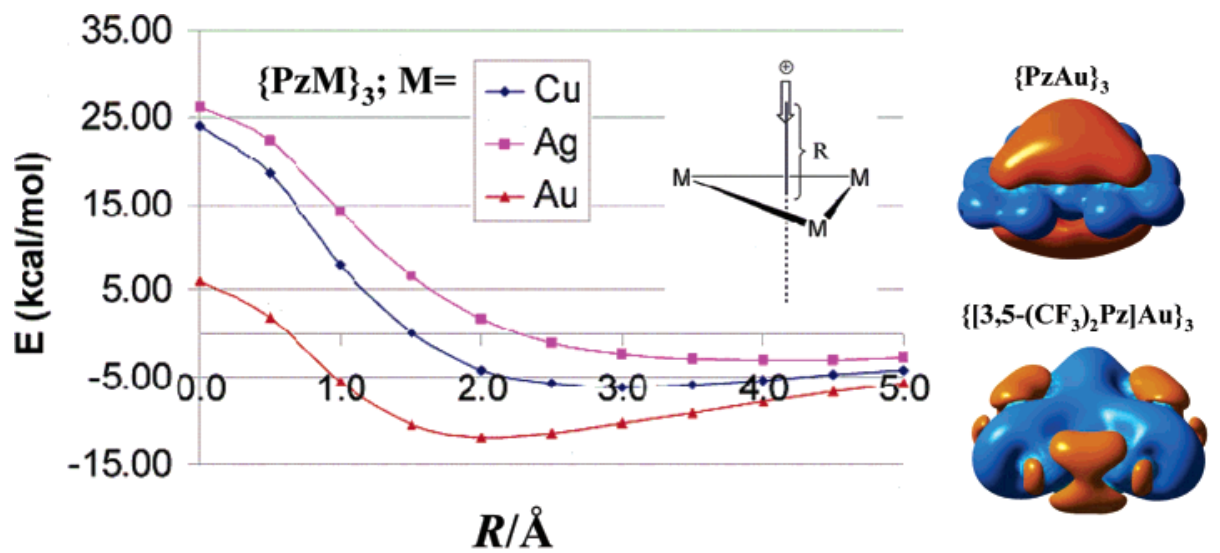

Figure 9. Left: Electrostatic attraction energy between $\{\mathrm{PzM}\}_{3}$ and a positive point charge moving along the 3-fold axis perpendicular to the $\{\mathrm{PzM}\}_{3}$ plane. Right: Positive or acidic (blue) and negative or basic (orange) regions of the MEP in space for $\{\mathrm{PzAu}\}_{3}$ and $\left\{\left[3,5-\left(\mathrm{CF}_{3}\right)_{2} \mathrm{Pz}\right] \mathrm{Au}\right\}_{3}$.

of-trimer units. The toluene-sandwiched dimers of $\mathbf{A u}_{\mathbf{3}}$ exhibit two alternating chair structures in the $\left\{\left[\mathbf{A u}_{3}\right]_{2}\right.$ : toluene $\}_{\infty}$ supramolecular stacks. One chair exhibits a pair of intertrimer $\mathrm{Au} \cdots \mathrm{Au}$ separations of $3.298 \AA$ each while this distance is $3.542 \AA$ in the alternating chair (Figure 10). Both these distances are notably shorter than those observed in the toluene-free precursor $\mathbf{A u}_{3}$ (3.885(1) and 3.956(1) $\AA$; see Figure 2). The shortest $\mathrm{Au} \cdots \mathrm{C}$ (toluene) distances of toluene: $\left[\mathbf{A u}_{3}\right]_{2}$ :toluene units are 3.288 and $3.354 \AA$. The closest distance between the toluene carbons and the other $\mathrm{Au}_{3}$ unit is $3.473 \AA$. These Au $\cdots \mathrm{C}$ distances are comparable to the van der Waals separation between $\mathrm{Au}$ and $\mathrm{C}$ (3.36 A). ${ }^{44}$

The fact that each toluene is sandwiched between two fluorinated trimeric $\mathrm{Au}{ }^{\mathrm{I}}$ complexes provides an experimental substantiation of the aforementioned MEP prediction regarding the relative role of $\mathrm{R}$ vs $\mathrm{M}$ on the acid-base behavior of $\left\{\left[3,5-(\mathrm{R})_{2} \mathrm{Pz}\right] \mathrm{M}\right\}_{3}$. The $\left\{\left[3,5-\left(\mathrm{CF}_{3}\right)_{2} \mathrm{Pz}\right] \mathrm{Au}\right\}_{3} \cdot 0.5$ (toluene) molecule represent the first acid-base adduct in which a trinuclear $\mathrm{Au}^{\mathrm{I}}$ complex acts as an acid. The acidic behavior of the $\left\{\left[3,5-\left(\mathrm{CF}_{3}\right)_{2} \mathrm{Pz}\right] \mathrm{Au}\right\}_{3}$ compound reported here is in sharp contrast to that of nonfluorinated trimeric $\mathrm{Au}^{\mathrm{I}}$ complexes with imidazolate and carbeniate bridging ligands, for which the groups of Fackler, ${ }^{1,4}$ Balch, ${ }^{3 b}$ and Aida ${ }^{6 b}$ have demonstrated their basic behavior. An interesting comparison exists for the present $\left[\mathbf{A u}_{3}\right]_{2} \cdot$ toluene adduct with an adduct reported by Fackler et al. to form between a trimeric $\mathrm{Au}^{\mathrm{I}}$ imidazolate complex and the organic acceptor TCNQ. ${ }^{4 c}$ Both adducts have 2:1 stacks with much shorter Au $\cdots$ Au separations than in the corresponding trimeric complex without the organic component. While the shortening in the TCNQ adduct with the basic trimeric complex was ascribed to a partial oxidation of the $\mathrm{Au}^{\mathrm{I}}$ trimer, we expect that the opposite (i.e., partial reduction of $\mathbf{A u}_{\mathbf{3}}$ ) is true in the toluene

(38) Kasha, M. Discuss. Faraday Soc. 1950, 9, 14.

(39) For reviews, see: (a) Callear, A. B. Chem. Rev. 1987, 87, 335. (b) Morse, M. D. Chem. Rev. 1986, 86, 1049.

(40) Ford, P. C.; Cariati, E.; Bourassa, J. Chem. Rev. 1999, 99, 3625.

(41) For example, see: Crosby, G. A.; Hager, G. D.; Hipps, K. W.; Stone, M. L. Chem. Phys. Lett. 1974, 28, 497 and references therein.

(42) Winnik, F. M. Chem. Rev. 1993, 93, 587.

(43) Moore, C. E. Atomic Energy Levels, Vol. III; United States Department of Commerce, National Bureau of Standards: Washington, DC, 1958.

(44) Winter, M. WebElements Periodic table (Professional Edition); accessible at http://www.webelements.com/. adduct here with the acidic fluorinated trimer. Chemical intuition dictates that partial reduction of the dimer-of-trimer model shown in Figure 5 will indeed lead to strengthening of the intertrimer $\mathrm{Au}-\mathrm{Au}$ bonding.

\section{Concluding Remarks}

In summary, varying the coinage metal in cyclic pyrazolate trimeric complexes substantially affects the solid-state packing, photophysics, and acid-base properties. The remarkable luminescence properties are manifested by the appearance of multiple unstructured phosphorescence bands whose colors and lifetimes change qualitatively upon varying the coinage metal and temperature. The luminescence variations exhibited by $\mathbf{M}_{3}$ crystals are related to internal conversions between multiple phosphorescent states with enhanced $\mathrm{M}-\mathrm{M}$ bonding. The trend in the lowest energy phosphorescence band follows the relative triplet energy of the three $\mathrm{M}^{\mathrm{I}}$ ions. DFT calculations suggest that $\left\{\left[3,5-(\mathrm{R})_{2} \mathrm{Pz}\right] \mathrm{M}\right\}_{3}$ trimers with $\mathrm{R}$ $=\mathrm{H}$ or $\mathrm{Me}$ are bases with the relative basicity order $\mathrm{Ag} \ll$ $\mathrm{Cu}<\mathrm{Au}$ while fluorination $\left(\mathrm{R}=\mathrm{CF}_{3}\right)$ makes even the $\mathrm{Au}$ trimer acidic. This prediction was substantiated by the isolation of an adduct in which toluene is sandwiched between dimer-of-trimer units of the fluorinated Au complex to form $\left\{\left[\mathbf{A u}_{3}\right]_{2} \text { :toluene }\right\}_{\infty}$ stacks. The findings of this work are guiding the synthesis and characterization of a variety of binary acid-base compounds with potential uses in optoelectronic applications, including molecular light-emitting devices and optical sensors.

\section{Experimental Methods}

Physical Measurements. The luminescence measurements were carried out at the University of North Texas for crystalline material carefully examined by optical microscopy. Steady-state luminescence spectra were acquired with a PTI QuantaMaster model QM-4 scanning spectrofluorometer. The excitation and emission spectra were corrected for the wavelength-dependent lamp intensity and detector response, respectively. Lifetime data were acquired using fluorescence and phosphorescence subsystem add-ons to the PTI instrument. The pulsed excitation source was generated using the $337.1 \mathrm{~nm}$ line of the $\mathrm{N}_{2}$ laser pumping a freshly prepared $1 \times 10^{-2}$ $\mathrm{M}$ solution of the continuum laser dye Coumarin-540A in ethanol, the output of which was appropriately tuned and frequency doubled to attain the excitation wavelengths needed based on the lumines- 

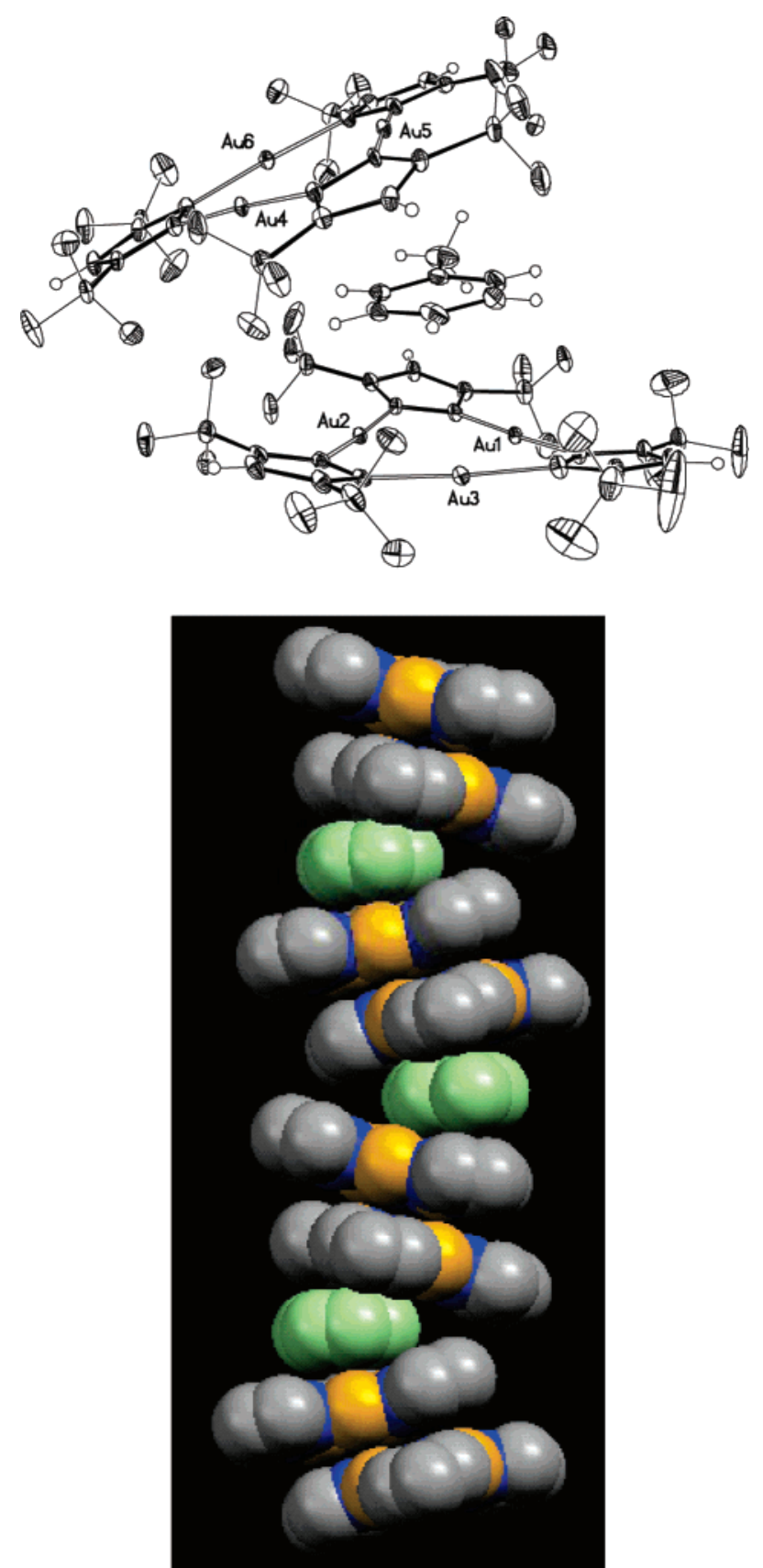

Figure 10. X-ray crystal structure of the adduct formed between $\{[3,5-$ $\left.\left.\left(\mathrm{CF}_{3}\right)_{2} \mathrm{Pz}\right] \mathrm{Au}\right\}_{3}$ and toluene. Top: ORTEP diagram of the $\left\{\left[3,5-\left(\mathrm{CF}_{3}\right)_{2} \mathrm{Pz}\right]\right.$ $\mathrm{Au}\}_{3} \cdot 0.5$ toluene asymmetric unit. Bottom: Stacking of the $\mathrm{Au}_{3} \mathrm{~N}_{6}$ metallacycle with toluene molecules. Selected bond distances $(\AA)$ and angles (deg): $\mathrm{Au}(1)-\mathrm{N}(23) 2.006(4), \mathrm{Au}(1)-\mathrm{N}(29) 2.016(4), \mathrm{Au}(2)-\mathrm{N}(37) 1.986$ (4), $\mathrm{Au}(2)-\mathrm{N}(17) 2.011(5), \mathrm{Au}(3)-\mathrm{N}(14) 2.006(5), \mathrm{Au}(3)-\mathrm{N}(24) 2.010-$ (5), $\mathrm{Au}(4)-\mathrm{N}(32)$ 1.997(5), $\mathrm{Au}(4)-\mathrm{N}(39)$ 2.002(5), $\mathrm{Au}(5)-\mathrm{N}(21) 2.000(4)$, $\mathrm{Au}(5)-\mathrm{N}(35) 2.002(5), \mathrm{Au}(6)-\mathrm{N}(36) 1.995(4), \mathrm{Au}(6)-\mathrm{N}(16) 1.999(4)$ $\mathrm{N}(23)-\mathrm{Au}(1)-\mathrm{N}(29) 175.74(17), \mathrm{N}(37)-\mathrm{Au}(2)-\mathrm{N}(17)$ 176.30(18), N(14)$\mathrm{Au}(3)-\mathrm{N}(24)$ 177.11(18), N(32)- $\mathrm{Au}(4)-\mathrm{N}(39)$ 176.05(18), N(21) - $\mathrm{Au}(5)-$ $\mathrm{N}(35)$ 176.96(19), $\mathrm{N}(36)-\mathrm{Au}(6)-\mathrm{N}(16) 176.87(19)$.

cence excitation spectra for each compound. Cooling in temperaturedependent measurements for the crystals was achieved using an Oxford optical cryostat, model Optistat CF ST, interfaced with a liquid-helium tank. Absorption spectra were acquired with a PerkinElmer Lambda 900 double-beam UV/vis/NIR spectrophotometer for solutions of crystalline samples prepared in HPLC-grade cyclohexane using standard 1-cm quartz cuvettes.

General Procedures. All manipulations were carried out under an atmosphere of purified nitrogen using standard Schlenk techniques. Solvents were purchased from commercial sources, distilled from conventional drying agents, and degassed by the freezepump -thaw method twice prior to use. Glassware was oven-dried at $150{ }^{\circ} \mathrm{C}$ overnight. NMR spectra were recorded at $25^{\circ} \mathrm{C}$ on a JEOL Eclipse 500 spectrometer $\left({ }^{1} \mathrm{H}, 500.16 \mathrm{MHz} ;{ }^{19} \mathrm{~F}, 470.62\right.$ $\mathrm{MHz}$ ). Proton chemical shifts are reported in ppm versus $\mathrm{Me}_{4} \mathrm{Si}$. ${ }^{19} \mathrm{~F}$ NMR chemical shifts were referenced relative to external $\mathrm{CFCl}_{3}$.

Syntheses. The preparation of $\left\{\left[3,5-\left(\mathrm{CF}_{3}\right)_{2} \mathrm{Pz}\right] \mathrm{Cu}\right\}_{3}$ and $\{[3,5-$ $\left.\left.\left(\mathrm{CF}_{3}\right)_{2} \mathrm{Pz}\right] \mathrm{Ag}\right\}_{3}$ was achieved by reported methods. ${ }^{10}$ The gold analogue $^{11}\left\{\left[3,5-\left(\mathrm{CF}_{3}\right)_{2} \mathrm{Pz}\right] \mathrm{Au}\right\}_{3}$ was prepared using the following method: $\left[3,5-\left(\mathrm{CF}_{3}\right)_{2} \mathrm{Pz}\right] \mathrm{H}(0.80 \mathrm{~g}, 3.90 \mathrm{mmol})$ was dissolved in dry tetrahydrofuran $(20 \mathrm{~mL})$ and treated with $60 \%$ excess of sodium hydride $(0.12 \mathrm{~g}, 4.96 \mathrm{mmol})$ at room temperature. The mixture was stirred for few minutes and filtered to remove unreacted sodium hydride. The filtrate was added to Au(THT)Cl (1.00 g, $3.09 \mathrm{mmol})$ at room temperature and stirred for $6 \mathrm{~h}$. The resulting mixture was filtered, and the precipitate was washed with tetrahydrofuran. The combined filtrate was evaporated under reduced pressure to obtain a white solid $(1.23 \mathrm{~g}, 60 \%)$. It was recrystallized from dichloromethane at $-25{ }^{\circ} \mathrm{C}$ to obtain $\mathrm{X}$-ray-quality crystals of $\{[3,5-$ $\left.\left.\left(\mathrm{CF}_{3}\right)_{2} \mathrm{Pz}\right] \mathrm{Au}\right\}_{3} .{ }^{11} \mathrm{Mp}: 210{ }^{\circ} \mathrm{C}(\mathrm{dec}) .{ }^{1} \mathrm{H}$ NMR $\left(\mathrm{C}_{6} \mathrm{D}_{6}\right): \delta 6.50(\mathrm{~s}$, $\mathrm{Pz} \mathrm{H}) .{ }^{19} \mathrm{~F}$ NMR $\left(\mathrm{C}_{6} \mathrm{D}_{6}\right): \delta-60.8\left(\mathrm{~s}, \mathrm{CF}_{3}\right)$. The $\left\{\left[3,5-\left(\mathrm{CF}_{3}\right)_{2} \mathrm{Pz}\right]-\right.$ $\mathrm{Au}\}_{3} \cdot 0.5$ toluene adduct was obtained by recrystallizing $\left\{\left[3,5-\left(\mathrm{CF}_{3}\right)_{2}-\right.\right.$ $\mathrm{Pz}] \mathrm{Au}\}_{3}$ from toluene at $-25{ }^{\circ} \mathrm{C}$. Mp: $220{ }^{\circ} \mathrm{C} .{ }^{1} \mathrm{H}$ NMR $\left(\mathrm{C}_{6} \mathrm{D}_{6}\right)$ : $\delta 7.01(\mathrm{~m}$, toluene $\mathrm{H}), 6.98(\mathrm{~m}$, toluene $\mathrm{H}), 6.49(\mathrm{~s}, 3 \mathrm{H}, \mathrm{Pz} \mathrm{H})$, 2.10 (s, toluene $\left.\mathrm{CH}_{3}\right) .{ }^{19} \mathrm{~F}$ NMR $\left(\mathrm{C}_{6} \mathrm{D}_{6}\right): \delta-60.8$.

X-ray Crystallography. X-ray-quality crystals of $\left\{\left[3,5-\left(\mathrm{CF}_{3}\right)_{2}-\right.\right.$ $\mathrm{Pz}] \mathrm{Ag}\}_{3}$ and $\left\{\left[3,5-\left(\mathrm{CF}_{3}\right)_{2} \mathrm{Pz}\right] \mathrm{Au}\right\}_{3}$ were obtained from $\mathrm{CH}_{2} \mathrm{Cl}_{2}$ solutions at $-25{ }^{\circ} \mathrm{C}$. The $\left\{\left[3,5-\left(\mathrm{CF}_{3}\right)_{2} \mathrm{Pz}\right] \mathrm{Au}\right\}_{3} \cdot 0.5$ toluene was obtained at $-25^{\circ} \mathrm{C}$ from a toluene solution. A suitable crystal from each sample covered with a layer of hydrocarbon oil was selected and mounted with Paratone-N oil on a Cryo-Loop and immediately placed in the low-temperature nitrogen stream. The X-ray intensity data were measured at 100(2) K on a Bruker SMART APEX CCD area detector system equipped with an Oxford Cryosystems 700 series cooler, a graphite monochromator, and a Mo K $\alpha$ fine-focus sealed tube $(\lambda=0.71073 \AA)$. The detector was placed at a distance of $5.995 \mathrm{~cm}$ from the crystal. The data frames were integrated with the Bruker SAINT-Plus (version 6.45) software package. Data were corrected for absorption effects using the multiscan technique (SADABS). The structures were solved and refined using Bruker SHELXTL (version 6.14) software package. All three compounds crystallize in the $P \overline{1}$ space groups. The solution and refinement proceeded smoothly. One of the $\mathrm{CF}_{3}$ groups of $\left\{\left[3,5-\left(\mathrm{CF}_{3}\right)_{2} \mathrm{Pz}\right]-\right.$ $\mathrm{Ag}\}_{3}$ displays a minor 3-fold rotational disorder over two positions, which was modeled successfully at $91 \%$ and $9 \%$ occupancy. The hydrogen atoms were placed in idealized positions and included as riding atoms. All non-hydrogen atoms were refined anisotropically (except for the $\mathrm{F}$ atoms in the minor component of the disordered $\mathrm{CF}_{3}$ ). A summary of the $\mathrm{X}$-ray data is presented in Table 1. Further details of the data collection and refinement are given in the CIF file. The $\left\{\left[3,5-\left(\mathrm{CF}_{3}\right)_{2} \mathrm{Pz}\right] \mathrm{Cu}\right\}_{3}$ structure was reported earlier. ${ }^{8 \mathrm{~b}}$ It also crystallizes in the $P \overline{1}$ space group.

\section{Computational Methods}

The calculations employed the GAMESS (molecular electrostatic potentials), Gaussian98 (preliminary sensitivity analyses for density functional theory (DFT) methods on trimer models), or Jaguar (DFT and MP2 calculations on dimer of trimer models) programs. ${ }^{45-47}$ The predicted geometries of the coinage metal pyrazolate trimer complexes were found to be insensitive to the methods (Hartree-

(45) Jaguar, version 5.5; Schrödinger, Inc.: Portland, OR (www.schrodinger.com). 
Omary et al.

Fock, pure and hybrid functionals, Møller-Plesset second-order perturbation theory (MP2)) and basis sets (Los Alamos, ${ }^{48}$ Stevens ${ }^{49}$ effective core potentials (ECPs), and basis sets) by comparison with experimental structures of known congeners. Production calculations

(46) Schmidt, M. W.; Baldridge, K. K.; Boatz, J. A.; Elbert, S. T.; Gordon, M. S.; Jensen, J. J.; Koseki, S.; Matsunaga, N.; Nguyen, K. A.; Su, S.; Windus, T. L.; Dupuis, M.; Montgomery, J. A. J. Comput. Chem. 1993, 14, 1347.

(47) Frisch, M. J.; Trucks, G. W.; Schlegel, H. B.; Scuseria, G. E.; Robb, M. A.; Cheeseman, J. R.; Montgomery, J. A., Jr.; Vreven, T.; Kudin, K. N.; Burant, J. C.; Millam, J. M.; Iyengar, S. S.; Tomasi, J.; Barone, V.; Mennucci, B.; Cossi, M.; Scalmani, G.; Rega, N.; Petersson, G. A.; Nakatsuji, H.; Hada, M.; Ehara, M.; Toyota, K.; Fukuda, R.; Hasegawa, J.; Ishida, M.; Nakajima, T.; Honda, Y.; Kitao, O.; Nakai, H.; Klene, M.; Li, X.; Knox, J. E.; Hratchian, H. P.; Cross, J. B.; Adamo, C.; Jaramillo, J.; Gomperts, R.; Stratmann, R. E.; Yazyev, O.; Austin, A. J.; Cammi, R.; Pomelli, C.; Ochterski, J. W.; Ayala, P. Y.; Morokuma, K.; Voth, G. A.; Salvador, P.; Dannenberg, J. J.; Zakrzewski, V. G.; Dapprich, S.; Daniels, A. D.; Strain, M. C.; Farkas, O.; Malick, D. K.; Rabuck, A. D.; Raghavachari, K.; Foresman, J. B.; Ortiz, J. V.; Cui, Q.; Baboul, A. G.; Clifford, S.; Cioslowski, J.; Stefanov, B. B.; Liu, G.; Liashenko, A.; Piskorz, P.; Komaromi, I.; Martin, R. L.; Fox, D. J.; Keith, T.; Al-Laham, M. A.; Peng, C. Y.; Nanayakkara, A.; Challacombe, M.; Gill, P. M. W.; Johnson, B.; Chen, W.; Wong, M. W.; Gonzalez, C.; Pople, J. A. GAUSSIAN'03; Gaussian, Inc.: Carnegie Office Park, Building 6, Suite 230, Carnegie, PA 15106, 2003

(48) Hay, P. J.; Wadt, W. R. J. Chem. Phys. 1985, 82, 270

(49) Parr, R. G.; Yang. W. Density-functional Theory of Atoms and Molecules; Oxford University Press: Oxford, U.K., 1989. therefore employed the Stevens ${ }^{49}$ potentials (SBK) for all heavy atoms and the $-31 \mathrm{G}$ basis set for hydrogen in conjunction with the B3LYP50 functional. Main group element basis sets were augmented with a d-polarization function taken from the $6-31 \mathrm{G}^{*}$ basis set. ${ }^{51}$ For calculations with Jaguar the all-electron $6-31 \mathrm{G}^{*}$ basis set was used for $\mathrm{H}, \mathrm{C}$, and N. Molecules were fully optimized within either $C_{s}$ or $C_{i}$ symmetry, and all species were characterized as minima by calculation of the energy Hessian at the appropriate level of theory.

Acknowledgment. Support by the National Science Foundation (CAREER Award Grant CHE-0349313 to M.A.O., Grant CHE-0309811 to T.R.C., and Grant CHE-0314666 to H.V.R.D.) and the Robert A. Welch Foundation (Grant B-1542 to M.A.O. and Grant Y-1289 to H.V.R.D.) is gratefully acknowledged.

Supporting Information Available: Crystallographic data in cif format. This material is available free of charge via the Internet at http://pubs.acs.org.

IC0508730

(50) Becke, A. D. J. Chem. Phys. 1993, 98, 5648

(51) (a) Hariharan, P. C.; Pople, J. A. Theor. Chim. Acta 1973, 28, 213. (b) Francl, M. M.; Pietro, W. J.; Hehre, W. J.; Binkley, J. S.; Gordon, M. S.; DeFrees, D. J.; Pople, J. A. J. Chem. Phys. 1982, 77, 3654 